November 26, 2008

\title{
Telecom Regulatory and Policy Environment in Sri Lanka: Results and Analysis of the 2008 TRE Survey
}

\author{
Malathy Knight-John
}

malathy@ips.1k

Research Fellow, Institute of Policy Studies, Sri Lanka 


\section{Table of Contents}

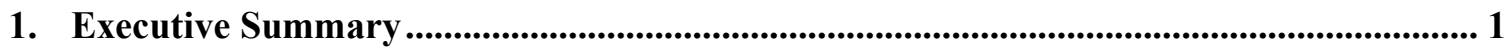

2. Methodology and Limitations.................................................................................................. 3

3. Development of the Telecom Regulatory and Policy Environment.................................... 5

3.1 Sri Lanka's Telecom Sector: A Macroeconomic Perspective ……....................................... 8

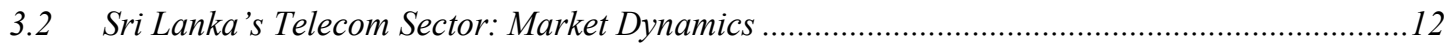

4. Results and Analysis of the TRE Survey for Sri Lanka ...................................................... 17

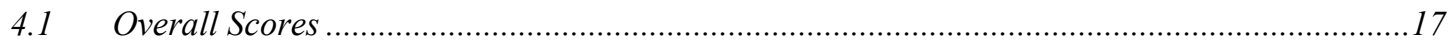

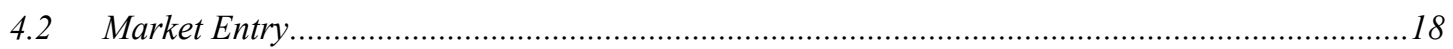

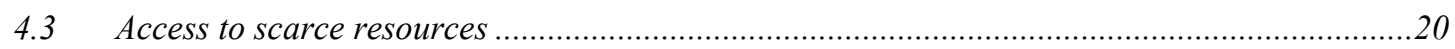

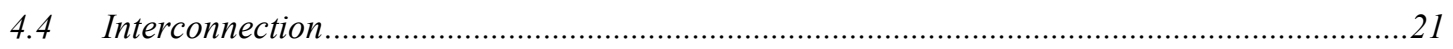

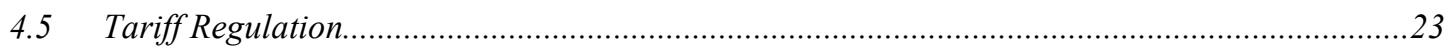

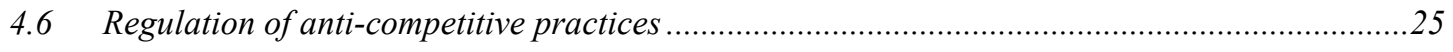

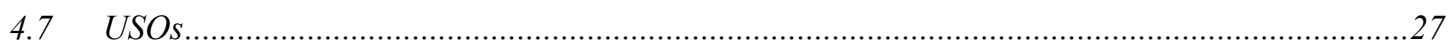

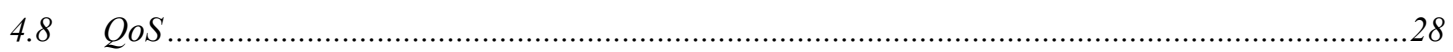

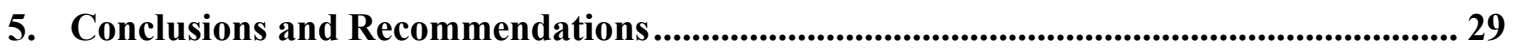

6. Acknowledgements ............................................................................................................................ 31

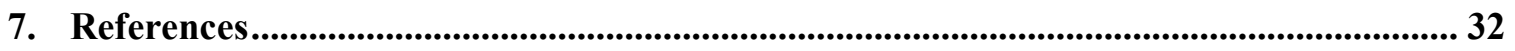

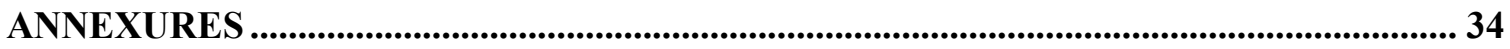

Annex 1: Fact sheet of key events in the telecom regulatory environment in Sri Lanka: May

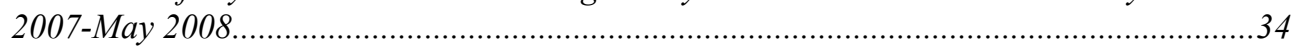

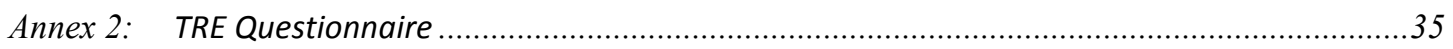

Annex 3: District-wise distribution of fixed phones (Non-CDMA and CDMA) as at

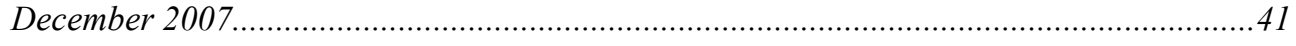

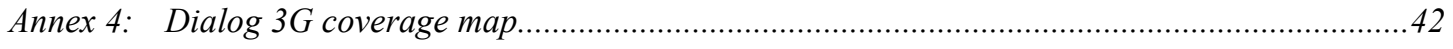

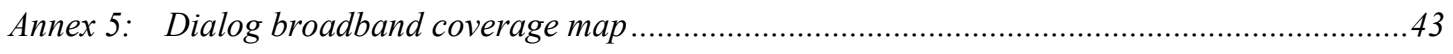

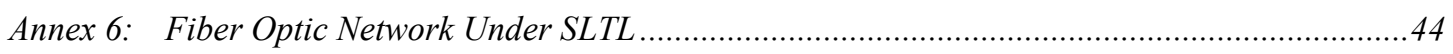




\section{List of Figures}

Figure 1: Linking key regulatory and policy events to subscriber growth in the fixed and mobile sectors (1992-2007) .......................................................................... 7

Figure 2: Fixed and mobile telephone growth in Sri Lanka, 1992-2007..................................... 10

Figure 3: Internet and broadband subscribers 1995-2007 ................................................................ 12

Figure 4: Fixed and mobile sector market shares: 2006 and 2007 ................................................ 14

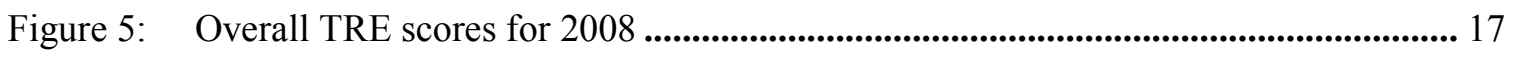

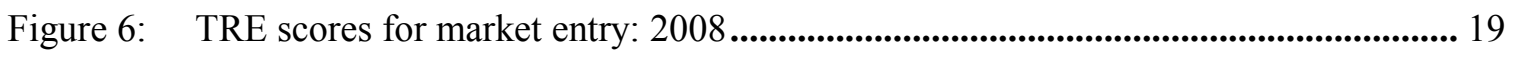

Figure 7: TRE scores for market entry: 2006 vs. 2008 ................................................................. 19

Figure 8: TRE scores for scarce resources: 2008 ......................................................................... 20

Figure 9: TRE scores for access to scarce resources: 2006 vs. 2008 ............................................ 21

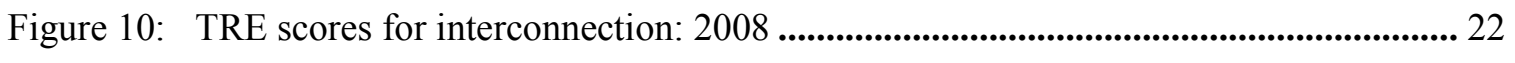

Figure 11: TRE scores for interconnection: 2006 vs. 2008 ................................................................ 22

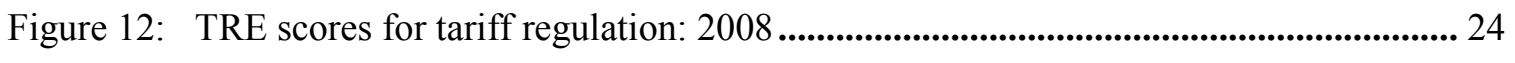

Figure 13: TRE scores for tariff regulation: 2006 vs. 2008................................................................. 24

Figure 14: TRE scores for anti-competitive practices: 2008 ......................................................... 26

Figure 15: TRE scores for anti-competitive practices: 2006 vs. 2008 .......................................... 27

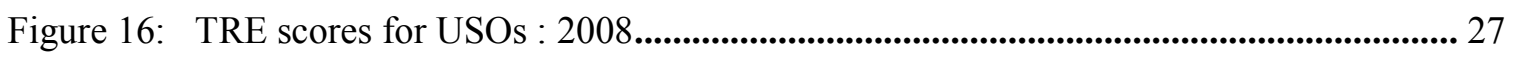

Figure 17: TRE scores for USOs: 2006 vs. 2008 ................................................................................. 28

Figure 18: TRE scores for QoS: 2008 ........................................................................................................ 29 


\section{List of Tables}

Table 1: $\quad$ Number of respondents and weights assigned to ensure equal contribution by each category to the final score .................................................................. 4

Table 2: Key regulatory and policy events: 1980-2008 .................................................................. 6

Table 3: Telecom sector contributions to government revenue ...................................................... 8

Table 4: A snapshot of Sri Lanka's telecom sector as at December 2007 .................................. 13

Table 5: Comparing the average TRE scores for 2005-2006 and 2007-2008 ............................ 18 


\section{List of Acronyms}
ADSL - Asymmetric Digital Subscriber Line
BOP - Bottom of the Pyramid
BWA - Broadband Wireless Access
CAA - Consumer Affairs Authority
CCPI - Colombo Consumer Price Index
CDMA - Code Division Multiple Access
CFS - Consumer Finance Survey
CPP - Calling Party Pays
CSE - Colombo Stock Exchange
EGO - External Gateway Operator
FCC - Federal Communications Commission
FDI - Foreign Direct Investment
GATS - General Agreement on Trade in Services
GDP - Gross Domestic Product
GOSL - Government of Sri Lanka
HHI - Herfindahl- Hirschman Index
ICTA - Information and Communication Technology Agency of Sri Lanka
ISPs - - Internet Service Providers
IP $\quad-\quad$ Internet Protocol
ITU - International Telecommunication Union
MOU - Memorandum of Understanding
NSOs - National Statistical Organizations
NTT - Nippon Telephone and Telegraph
OECD - Organization for Economic Co-operation and Development
QoS - Quality of Service
PSTN - Public Switched Telephone Network
RPP - Receiving Party Pays
SLTL - Sri Lanka Telecom Limited
TRC - $\quad$ Telecom Regulatory Commission of Sri Lanka
TRE - Telecom Regulatory Environment
USOs - Universal Service Obligations 
VOIP - Voice Over Internet Protocol

WLL - Wireless Local Loops

WiMAX - World Wide Interoperability for Microwave Access 


\section{Executive Summary}

The 2008 TRE survey is a perception based assessment by informed stakeholders in the telecom industry regarding the efficacy of regulation and policy with respect to seven dimensions in the fixed, mobile and broadband sectors: market entry, access to scarce resources, interconnection, tariff regulation, anti-competitive practices, USOs and QoS. Key regulatory and policy episodes that occurred in the May 2007 to May 2008 time period provide a contextual background to the survey questionnaire. This report also compares the 2008 survey results with those of a similar survey conducted in 2006 to arrive at a better understanding of the dynamics underlying the TRE scores.

The results of the 2008 TRE survey indicate a below average score across six of the seven dimensions, with the exception being mobile sector USOs. The key facts that emerge from a comparison of the two survey periods, 2006 and 2008, is that overall TRE scores have improved marginally in both the fixed sector and in the mobile sector; scores for market entry in the mobile sector have shown a significant drop; scores for fixed sector interconnection have increased significantly; and, scores for USOs in both sectors have recorded increases.

However, our analysis of the TRE scores for Sri Lanka indicates that these numbers are not entirely a reflection of regulatory and policy actions (as in the case of the comparative TRE scores for interconnection between 2006 and 2008 for instance) or of market dynamics (as in the case of tariff regulation for the period between 2006 and 2008 for instance). In addition, our analysis suggests that disparities between the definition of a particular parameter contained in the survey questionnaire and the perception of respondents as to the definition of a particular parameter could also bias the results of the TRE scores (as for instance in the USOs category).

In general however, what emerges from our analysis is that market behavior - specific actions taken by operators - in spite of bad regulatory and policy actions - facilitated by the dynamics of competition, is driving the telecom sector. Initial pro-competitive 
reforms and liberalization efforts from 1980 until the mid-late 1990s created a momentum for competition that appears to have taken off, by-passing regulation.

The policy recommendations emerging from our analysis focus on the principles regulation only where necessary; and, regulation for competition. For instance, we argue that areas such as tariff regulation and QoS should be left to the market - according to the tenets of consumer choice and revealed preference, whilst areas such as interconnection, licensing and access to scarce resources need to be addressed in a systematic and transparent basis by the regulator. 


\section{Methodology and Limitations}

The TRE instrument, which is a diagnostic tool designed to assess the efficacy of regulation and policies pertaining to a particular country's telecom sector was developed by LIRNEasia and is set out in detail in (Samarajiva et al, 2007). The TRE methodology was applied previously in Sri Lanka in 2004 and in 2006 for the fixed and mobile subsectors; this year's TRE survey includes the broadband sub-sector as a new component in the analysis of telecom sector performance. In this report, the TRE methodology is used to capture the perceptions of informed stakeholders on the telecom regulatory and policy environment of Sri Lanka, based on seven parameters: market entry; access to scarce resources; interconnection; tariff regulation; regulation of anti-competitive practices; universal service obligations; and, quality of service.

Survey respondents were asked to rate the quality of Sri Lanka's telecom regulatory and policy environment for each of the seven parameters on a Likert scale of 1 to 5, with 1 being highly unsatisfactory and 5 being highly satisfactory. A fact sheet of key policy and regulatory actions in the sector in the period May 2007-May 2008 (contained in Annex 1) was attached to the questionnaire (Annex 2) to provide some context to the survey.

The respondents of the TRE survey were divided into three categories as set out below:

- Category 1: Stakeholders directly affected by telecom sector regulation (such as operators, industry associations, equipment suppliers and investors)

- Category 2: Stakeholders who analyze the sector with broader interest (such as equity research analysts, credit rating agencies, telecom consultants and law firms)

- Category 3: Stakeholders with an interest in improving the sector to help the public (such as academics, research organizations, journalists, telecom user groups, civil society, former members of regulatory and other government agencies, donors, current government employees with knowledge on the telecom sector EXCLUDING those directly in the telecom regulatory and policy hierarchy - i.e. excludes anyone from the TRC and the Ministry of Posts and Telecom)

The total sample size of the survey was 124 and the response rate was 78.22 percent. The survey was conducted via different modes: online (web and email) and paper (in- 
person and fax). The rates of response categorized mode-wise indicate that a majority of the respondents (53.60\%) preferred a web-based survey.

The response rates for Category 1, 2 and 3 were $58 \%, 79 \%$ and $91 \%$ respectively; stakeholders that are most directly impacted by telecom sector regulation showed the lowest rate of response, relatively. Informal conversations with this category of stakeholders - in particular telecom sector operators - suggests that this group is rather skeptical, perceiving such exercises in relation to telecom sector regulation as being futile; several stakeholders in this category indicated that any positive outcome in sector performance, particularly in recent years, was in spite of bad regulation and policy.

As per the TRE methodology each category must contribute equally to the final score. However, given that it is not always practically possible to obtain an equal number of respondents from each category, we use weights to equalize the contributions per category. These weights are shown in Table 1.

Table 1: Number of respondents and weights assigned to ensure equal contribution by each category to the final score

\begin{tabular}{|c|c|c|}
\hline Category & No. of Respondents & Weights by LIRNEasia \\
\hline 1 & 22 & 1.617 \\
\hline 2 & 23 & 1.4058 \\
\hline 3 & 52 & 0.5985 \\
\hline
\end{tabular}

The limitations we encountered in running the TRE survey in Sri Lanka are as follows:

- The operators - coming within the category directly affected by telecom sector regulation and policy - were the most difficult to get responses from.

- Specific questions were left unanswered - for example, questions on broadband interconnection and on USOs were left unanswered by most respondents.

- Respondents tended to misunderstand terms used in the survey - for instance, several respondents failed to keep in mind that the TRE assessment is on the regulation of the market rather than on market performance per se. 
- Inability to obtain important, relevant and up to date indicator data from the TRC - the reason we were given was that there was an "internal technical malfunction" at the TRC.

\section{Development of the Telecom Regulatory and Policy Environment}

The Telecom Regulatory and Policy Environment study for Sri Lanka is based on the combined results of the 2008 TRE survey, on telecom indicator data from NSOs, telecom operators and the TRC and on key developments in the telecom regulatory and policy space in Sri Lanka in the period May 2007- May 2008. The principal research questions that this study aims to address are: how has the regulatory and policy environment pertaining to the telecom sector in Sri Lanka evolved over time; how has the telecom sector performed over time (as per the indicator data); to what extent is the performance of the telecom sector a result of regulatory and policy events; what do the results of the 2008 TRE survey point to with regard to the efficacy of regulatory and policy decisions in the fixed, mobile and broadband sectors; and what policy conclusions and recommendations can we draw from the results of this survey.

This section of the report focuses on the development of the regulatory and policy environment in Sri Lanka as shown in Table 2 and in Figure 1- picking on key events from 1980 (the year that marked the inception of telecom reform in Sri Lanka with the de-linking of posts and telecom service provision) to May 2008 - and on the performance of the telecom sector over time using 1996 as "Year One" ( $t=1)$, given the occurrence of significant reform and regulatory events such as the entry of the fourth mobile operator Dialog in 1995, the licensing of WLL operators in 1996 that posed a credible threat of contestability to the fixed sector incumbent SLTL, progressive amendments to the telecom regulatory legislation in 1996, and the partial privatization of SLT in 1997. Section 4 of this report analyzes the results of the 2008 TRE survey in an attempt to evaluate the efficacy of telecom policy and regulation in Sri Lanka and its impact on sector performance (based on the perceptions of informed stakeholders); and, to provide policy recommendations contained in Section 5. 
Table 2: Key regulatory and policy events: 1980-2008

\begin{tabular}{|c|c|}
\hline Year & Regulatory/policy event \\
\hline 1980 & De-linking of posts and telecom service provision \\
\hline 1989 & 1st private operator enters market (Celltel- mobile operator) \\
\hline 1991 & Legislation to set up regulatory agency (one-man-authority); Corporatization of incumbent \\
\hline 1994 & National Telecom Policy issued by GOSL (covering USOs, cost-based tariffs, QoS etc.) \\
\hline 1996 & $\begin{array}{l}\text { Licensing of WLL operators (Suntel \& Lanka Bell); Amendment to 1991 legislation (5- } \\
\text { member Commission- however, Sec to Ministry as ex-officio Chair of TRC); (yet another) } \\
\text { National Telecom Policy }\end{array}$ \\
\hline 1997 & $\begin{array}{l}\text { Incumbent (SLTL) partially privatized (NTT: } 35 \% \text {, GOSL: } 61.5 \% \text {, Employees } 3.5 \% \text { ); GOSL } \\
\text { commits to not issuing additional licenses for international telephony until August 2002; Sri } \\
\text { Lanka makes WTO commitments }\end{array}$ \\
\hline 1998-1999 & $\begin{array}{l}\text { Fixed telephony interconnection determination issued by TRC; SLTL appeals determination } \\
\text { in courts - fails to stay it (1999); } 1 \text { st stage of tariff rebalancing commences ( } 5 \text { stage } \\
\text { rebalancing exercise); TRC issues and implements fixed:mobile interconnection } \\
\text { determination; Beginning of court cases w.r.t. interconnection }\end{array}$ \\
\hline 2002 & $\begin{array}{l}\text { SLTL acquires balance } 60 \% \text { shares of Mobitel, making it the sole owner of the mobile } \\
\text { operator; SLT shares traded on the CSE (and subsequent re-mix of shares as: NTT } 35.2 \% \text {, } \\
\text { Public } 11.8 \% \text {, Employees } 3.5 \% \text {; GOSL } 49.5 \% \text { );All court cases except one withdrawn }\end{array}$ \\
\hline 2003 & $\begin{array}{l}\text { Exclusivity on international telephony ends with issuance of EGO licenses (for a fee of USD } \\
50,000 \text { ); Interconnection Rules gazetted; First assignment by auction of } 1800 \text { GSM } \\
\text { frequencies; Final tariff rebalancing implemented (a year late); ADSL broadband services } \\
\text { launched by SLTL }\end{array}$ \\
\hline 2004 & $\begin{array}{l}\text { VSNL (a subsidiary of India's USD } 29 \text { billion Tata Group) that obtained an EGO license in } \\
2003 \text {, commences operations in the international wholesale voice and data markets; TRC } \\
\text { decision on the implementation of CPP was reversed by the ex-officio Chair of the } \\
\text { Commission just hours before a news conference to announce a shift from RPP to CPP (the } \\
\text { alleged reason given by the Chair was the political ramifications of the decision just before an } \\
\text { election); Public hearing was held on the decision, the public hearing committee counted the } \\
\text { number of pro and con submissions and concluded that the public was against CPP (although } \\
\text { evidence pointed to the fact that the con submissions were orchestrated by a union) }\end{array}$ \\
\hline 2005 & $\begin{array}{l}\text { CDMA frequencies assigned; Court case between seven operators and ICTA with regard to } \\
\text { alleged exclusivity clauses in regional telecom network licenses; Consumer lobby takes TRC } \\
\text { and SLTL to court over 5th (final) tariff re-balancing exercise }\end{array}$ \\
\hline 2006 & $\begin{array}{l}\text { Sri Lanka's 1st commercial 3G mobile license issued; SLT foreign currency debt outlook } \\
\text { revised from stable to negative by Fitch Ratings; TRC issues call for 5th mobile operator }\end{array}$ \\
\hline 2007 & $\begin{array}{l}\text { TRC issued license to a fifth mobile operator Bharti Airtel.; Mobile subs levy of } 10 \% \text { of } \\
\text { every bill imposed on mobile users; WiMax broadband services launched by Dialog }\end{array}$ \\
\hline 2008 & $\begin{array}{l}\text { Mobile subs levy extended to non-mobile wireless phones (CDMA); Malaysia's Usaha Tegas } \\
\text { (UT) group bought over NTT's shares in SLTL ( } 35.2 \% \text { ), GOSL shares in SLTL reduced to } \\
49.5 \% \text { with the balance } 15.3 \% \text { shares being owned by SLTL employees and the public; } \\
\text { VSNL, which has } 30 \% \text { of Sri Lanka's outgoing voice traffic, rebrands itself as Tata } \\
\text { Communications (Lanka) in a corporate strategy aimed at expanding its international service } \\
\text { portfolio - in particular to leverage the Tata Global Network (one of the most advanced } \\
\text { submarine and IP networks) to meet the country's demand for converged IP solutions; Lanka } \\
\text { Bell invests Rs.3 billion to link to the } 65,000 \text { km FLAG undersea global fiber optic network } \\
\text { owned by India's Reliance group. }\end{array}$ \\
\hline
\end{tabular}

Source: Complied using information from the TRC and from key stakeholders in the telecom sector. 
Figure 1: Linking key regulatory and policy events to subscriber growth in the fixed and mobile sectors (1992-2007)

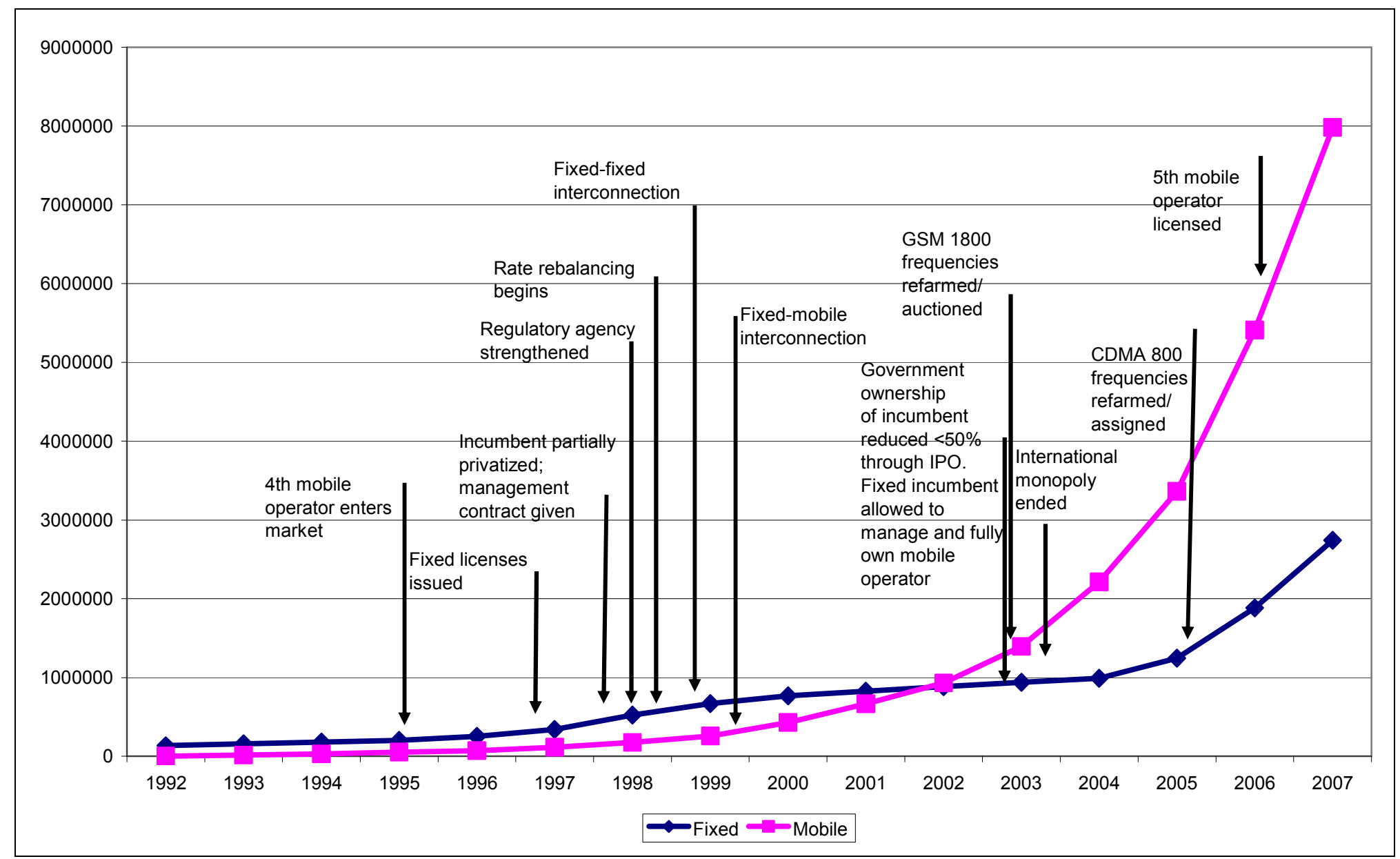

Source: TRC and industry information gathered from key stakeholders in the telecom sector. 


\subsection{Sri Lanka's Telecom Sector: A Macroeconomic Perspective}

Sri Lanka's telecom sector has evolved over time to become one of the foremost drivers of economic growth in the country. According to data from the Central Bank of Sri Lanka, the telecom sector contributed 2.37 percent to GDP in 2004 with this figure increasing up to 3.04 percent in $2007 .^{1}$ Mid-year economic performance indicators for 2008 released by the Department of Census and Statistics also show that the telecom and posts sub-sectors grew at 23.2 percent in the second quarter of 2008 as against 21 percent in the corresponding period of $2007^{2}$; it is reasonable to assume that this growth momentum comes largely from the telecom - as opposed to the posts sub-sector - given the operating losses of Rs. 3,797 million reported by the Department of Posts in 2007 (Central Bank of Sri Lanka, 2007).

Moreover, as shown in Table 3, numbers cited in the Fiscal Management Reports of 2007 and 2008 -issued under the Fiscal Management (Responsibility) Act No. 3 of 2003

- further indicates that the telecom sector is one of the largest contributors to government revenues relative to other state-owned profit-making institutions.

Table 3: Telecom sector contributions to government revenue

\begin{tabular}{|l|c|c|c|}
\hline Entity & \multicolumn{3}{|c|}{ Contributed amount (LKR Millions) } \\
\hline & $\begin{array}{c}\mathbf{2 0 0 5} \\
\text { (actuals) }\end{array}$ & $\begin{array}{c}\mathbf{2 0 0 7} \\
\text { (actuals) }\end{array}$ & $\begin{array}{c}\mathbf{2 0 0 8} \\
\text { (projected) }\end{array}$ \\
\hline TRC & 1,150 & 3,500 & 4,500 \\
\hline SLTL & 449 & 1,000 & 2,000 \\
\hline Bank of Ceylon & 1,150 & 1,673 & 1,846 \\
\hline People's Bank & 818 & 1,368 & 1,316 \\
\hline National Savings Bank & 1,310 & 1,310 & 1,560 \\
\hline
\end{tabular}

Source: Ministry of Finance and Planning, Sri Lanka

${ }^{1}$ Central Bank of Sri Lanka, Annual Reports, various years.

2 See http://www.statistics.gov.lk. 
Reliable data on the quantum of investment flows that can be attributed to the telecom sector is not available in Sri Lanka, given that this information is not published by the NSOs or the TRC. However, statements made by the country's investment promotion office, the Board of Investment, suggest that the telecom sector accounted for most of the USD 425 million FDI flows in the first six months of 2008. ${ }^{3}$

The direct benefits that the telecom sector has on the public are illustrated in Figure 2 which shows an increase in the number of subscribers both in the fixed and in the mobile sectors from 1992-2007. The growth in mobile sector subscribers shown in Figure 2 moreover, underestimates the actual figures to some degree as it is based on the number of SIM cards issued and does not capture usage patterns such as shared access. Positive trends in the telecom sector are also reflected in the reduction in regional (Provincial) disparities in access to services and in affordability - the lower cost of getting connected.

According to the Central Bank's Consumer and Finance Survey 2003-2004, whilst the Western Province had the largest number of households with telephones (44\% in 2001 and $45.5 \%$ in 2004), household access to telephones in hitherto neglected Provinces such as the Northern Province, Eastern Province, North Central Province, and the North Western Province increased from $3.5 \%$ to $19.5 \%$; $9.5 \%$ to $14 \%$; $7 \%$ to $14 \%$; and from $9 \%$ to $23 \%$, respectively in just three years between 2001-2004. (See Annex 3, 4 and 5 for a tabulation of district-wise fixed phones distribution as at December 2007; and, Dialog 3G and broadband coverage maps, respectively). Research conducted by (Zainudeen et al., 2007) further indicates that 41 percent of the poorest households - at the BOP - have telephones in their households; the CFS of 2003-2004 showed that 25 percent of all households in Sri Lanka (excluding the Killinochchi, Mannar and Mullaitivu districts) had either a fixed, mobile or both types of phones indicating a rapid increase in household connectivity in less than three years.

3 Lanka Business Online. “Tele Domination”, August $26^{\text {th }} 2008$ at: http://www.lankabusinessonline.com/ fullstory.php?nid=319076034. 
Figure 2: Fixed and mobile telephone growth in Sri Lanka, 1992-2007

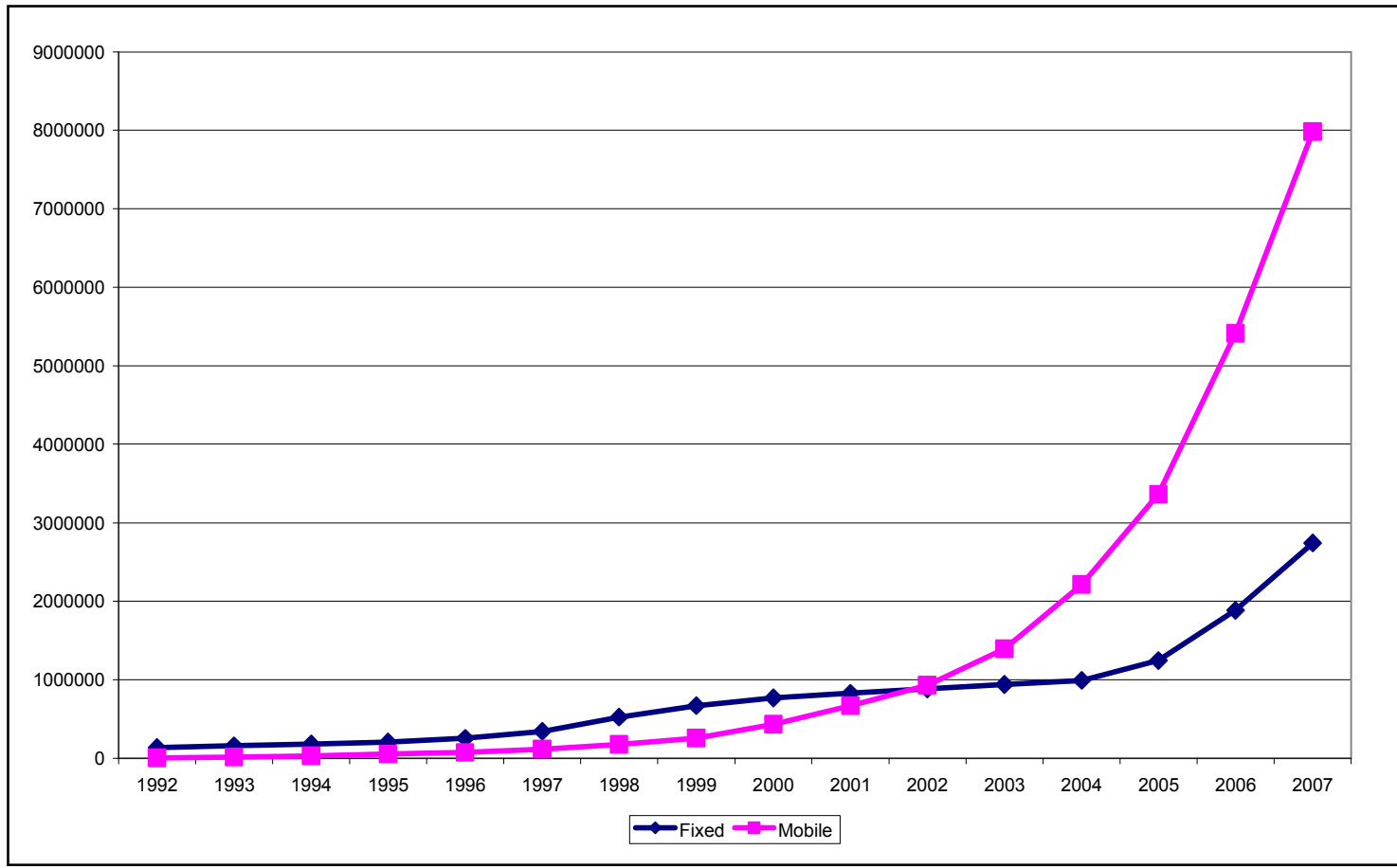

Source: TRC

The benefits of liberalization and competition are also reflected in the costs of owning and using a telephone. For instance, international call charges dropped by approximately 70 percent following the ending of SLTL's exclusivity on international telephony services in 2003 (Knight-John, 2007). As at the time of writing moreover, Sri Lanka's second largest fixed access provider, Lanka Bell, has announced that it will pay back subscribers that receive international calls 50 cents for every minute, regardless of country of origin, number of calls received per day or call duration. Whilst company representatives describe this action as one of passing on some of the benefits from its Rs.3 billion investment in the FLAG undersea fiber optic cable network to its users, it is also clear that this move is a competitive strategy aimed at growing Lanka Bell's international telephony market.

Research conducted by LIRNEasia benchmarking mobile tariffs in South Asia - using OECD "basket methodology"4 - also shows that Sri Lanka had relatively low mobile

${ }^{4}$ See http://lirneasia.net/projects/benchmarks. 
prices, although not the lowest in the region, as at October 2008. However, recent actions taken by the mobile operators to slash prices on the lines of what could be termed a budget telecom network business model could well see a change in Sri Lanka's ranking in terms of mobile tariffs in the region. The past few months has witnessed a price war in the mobile sector initiated by Mobitel, (Sri Lanka's second largest mobile operator in terms of numbers of active SIMs), followed by Dialog (the dominant mobile operator) announcing a discount package that would extend to its entire customer base of 4.5 million users. More recently in October 2008, Tigo (Sri Lanka's third largest operator in terms of numbers of active SIMs) advertised a new tariff scheme that renders all incoming calls free, effectively ending the RPP regime in Sri Lanka. Given that the regulator has, since 1999, failed to put CPP in place for various rather dubious reasons these actions by the operators are further evidence of solutions derived by the market in spite of bad regulation.

The results of a benchmarking exercise on broadband prices in South Asia, conducted by LIRNEasia in October 2008, show that Sri Lanka had the lowest prices for a $2 \mathrm{MB}$ broadband business connection and relatively low prices for a $256 \mathrm{kbps}$ broadband residential connection. ${ }^{5}$ However, the benefits of lower costs are offset to some extent by the quality of broadband service in the country, with users actually getting less than the advertised download speeds they pay for. ${ }^{6}$ As illustrated in Figure 3 moreover, the number of broadband subscribers lags behind internet subscribers, with dial-up being the more widespread mode of connecting to the internet.

Currently, SLTL has a legal monopoly on the provision of ADSL services. However, there is some degree of competition in the market with operators providing broadband services using wireless technologies - for instance Lanka Bell and Dialog (WiMax) and Mobitel ( $3.5 \mathrm{G})$ A comparison of Figures 2 and 3 suggest that there is significant potential for growing the broadband market with Sri Lanka having only 200,000 internet subscribers compared to eight million mobile subscribers as at December 2007; the gap

\footnotetext{
${ }^{5}$ See http://lirneasia.net/projects/benchmarks.

${ }^{6}$ See http://lirneasia.net/2006/05/100000-adsl-connections-how-about-speed.
} 
in the trend lines between internet and broadband subscribers illustrated in Figure 3 also indicates the presence of a huge untapped consumer base.

Figure 3: Internet and broadband subscribers 1995-2007

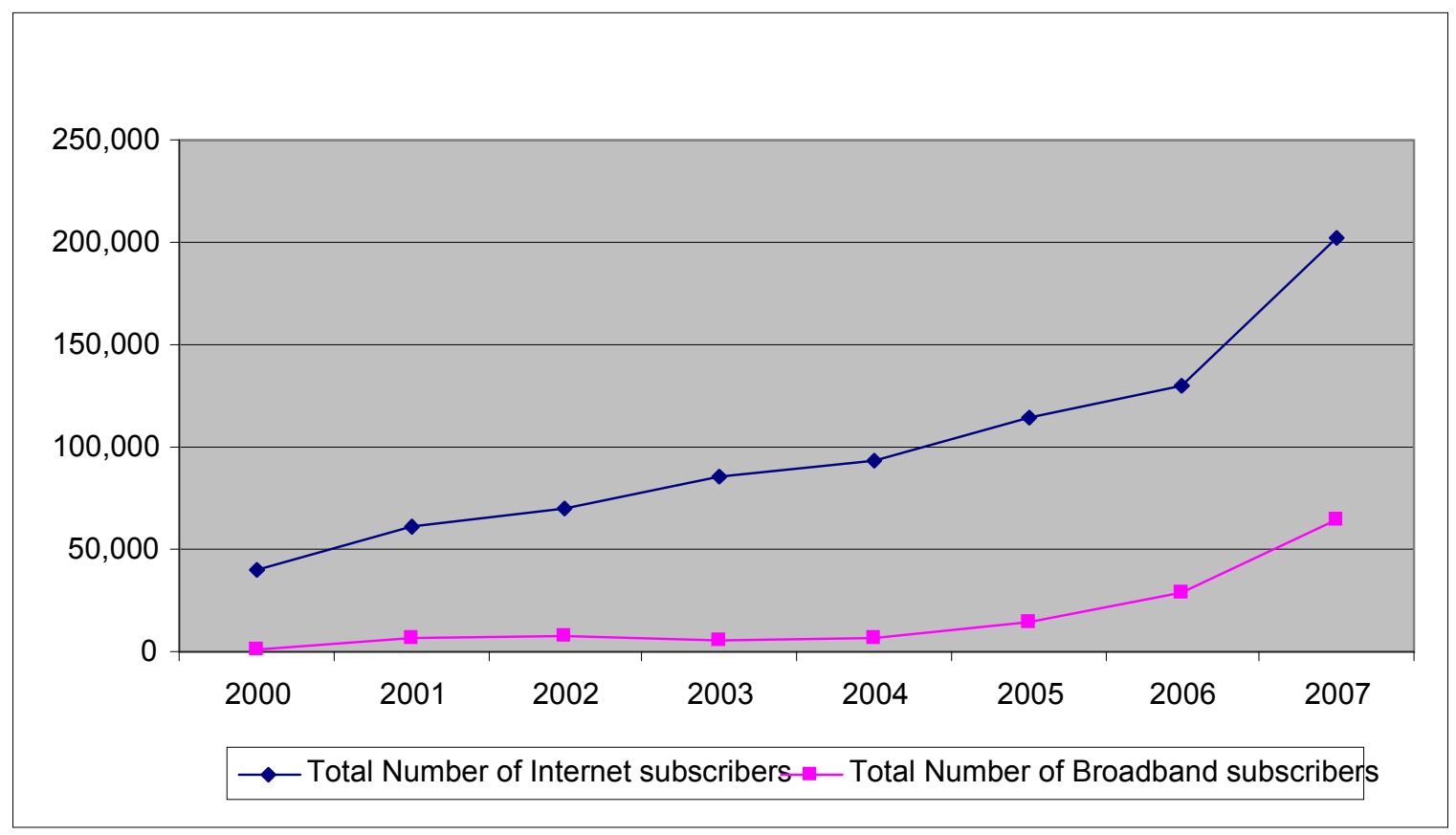

Source: TRC

\subsection{Sri Lanka's Telecom Sector: Market Dynamics}

A snapshot of the telecom sector in terms of the numbers and categories of operators as at December 2007 is shown in Table 4 below. The discrepancy between the reported number of licenses issued by the TRC and the actual number of active operators is a reflection, at least in two instances, of bad regulatory practice. First, the fact that Bharti Airtel is still not operational as at the time of writing despite the fact that it was issued a license in April 2007 does not send out positive signals to the investment community particularly with the company issuing media statements to the effect that its entry into the Sri Lankan market is being blocked by a discriminatory stance adopted by the existing mobile operators in terms of interconnection. On the other hand, the issuance of the Airtel license for USD 4 million in itself did not adhere to Sri Lanka's procedural commitment to the GATS Reference Paper on the public availability of licensing criteria. Second, whilst 32 EGO licenses were issued at a fee of USD 50,000, only 19 of the licensed 
operators are in operation due to interconnection issues with the PSTN operators, with the TRC failing to implement the Interconnection Rules gazetted in March 2003 (Samarajiva, 2007).

Table 4: A snapshot of Sri Lanka's telecom sector as at December 2007

\begin{tabular}{|l|c|l|}
\hline Category of service & $\begin{array}{c}\text { Number of } \\
\text { licenses }\end{array}$ & Notes \\
\hline Fixed telephony & 4 & $\begin{array}{l}\text { SLTL, Lanka Bell, Suntel and Dialog } \\
\text { CDMA }\end{array}$ \\
\hline Mobile telephony & 5 & $\begin{array}{l}\text { Dialog, Mobitel, Hutch, Tigo and } \\
\text { Bharti Airtel } \\
\text { (However Airtel is not operational in } \\
\text { the market as at the time of writing } \\
\text { despite the issuing of license in } \\
\text { April 2007) }\end{array}$ \\
\hline $\begin{array}{l}\text { Data communication services } \\
\text { facilities based) }\end{array}$ & 6 & Only 19 are operational \\
\hline $\begin{array}{l}\text { Data communications services (non- } \\
\text { facilities based) \& ISPs }\end{array}$ & 24 & Dialog Broadband Network \\
\hline $\begin{array}{l}\text { Trunked mobile radio network } \\
\text { services }\end{array}$ & 2 & Only 19 are operational \\
\hline Leased line services & 1 & Dialog TV \\
\hline Public payphone services & 32 & Lanka Broadband Networks \\
\hline EGOs & 1 & \\
\hline $\begin{array}{l}\text { Direct-to-home satellite broadcasting } \\
\text { service }\end{array}$ & 1 & \\
\hline Cable TV distribution network & & \\
\hline
\end{tabular}

Source: TRC

Figure 4 below shows fixed and mobile market shares and concentration ratios for the years 2006 and 2007. The picture that emerges from this calculation is that Lanka Bell has captured significant market share between 2006 and 2007; that the mobile sector is less concentrated than the fixed sector; and, that the level of concentration in the mobile sector has dropped between 2006 and 2007. 
Figure 4: Fixed and mobile sector market shares: 2006 and 2007

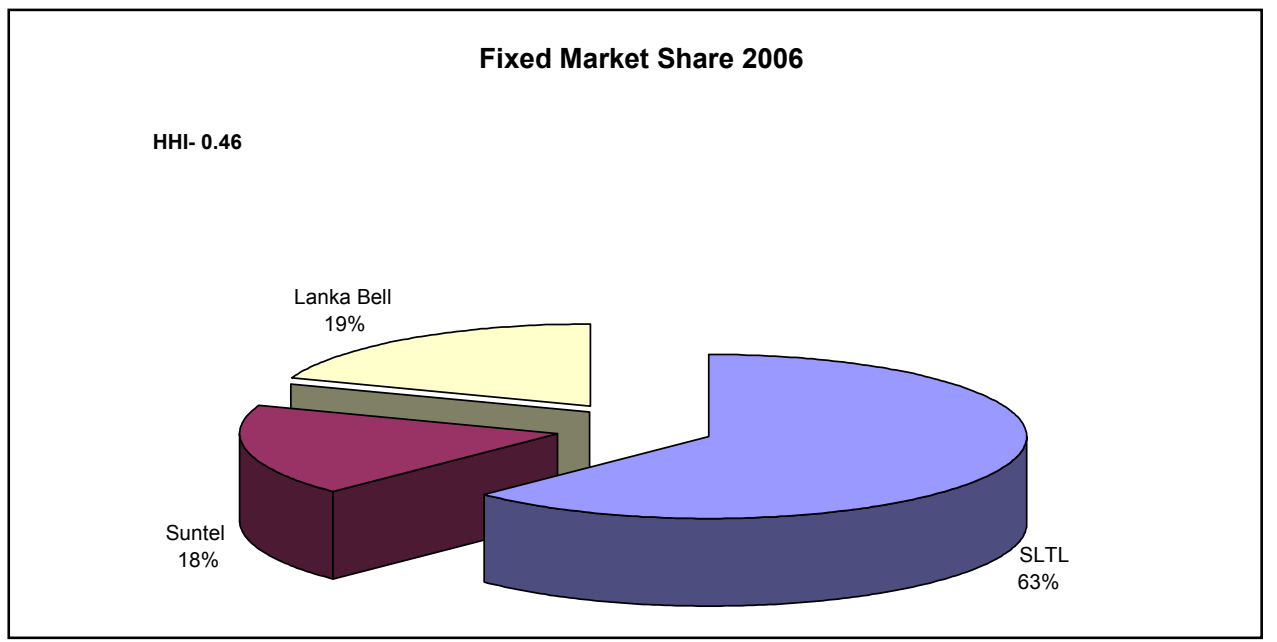

Note: Calculated based on subscriber numbers.

Source: Industry sources.

Fixed Market Share 2007

HHI- $\mathbf{0 . 4 0}$

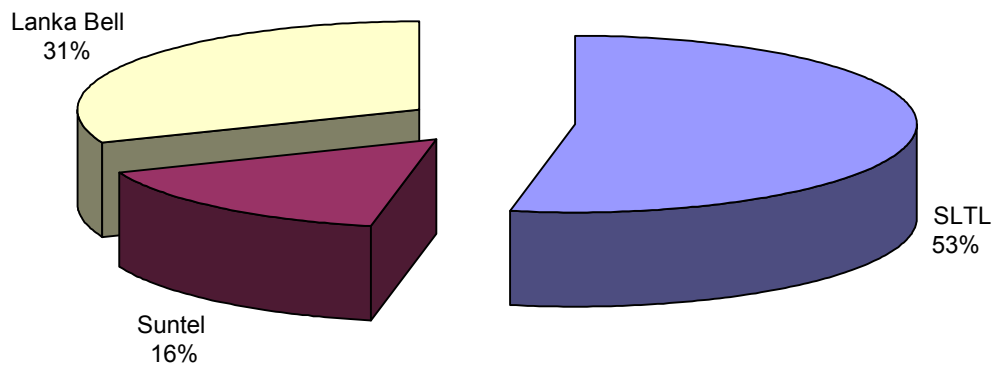

Note: Calculated based on subscriber numbers.

Source: Industry sources. 


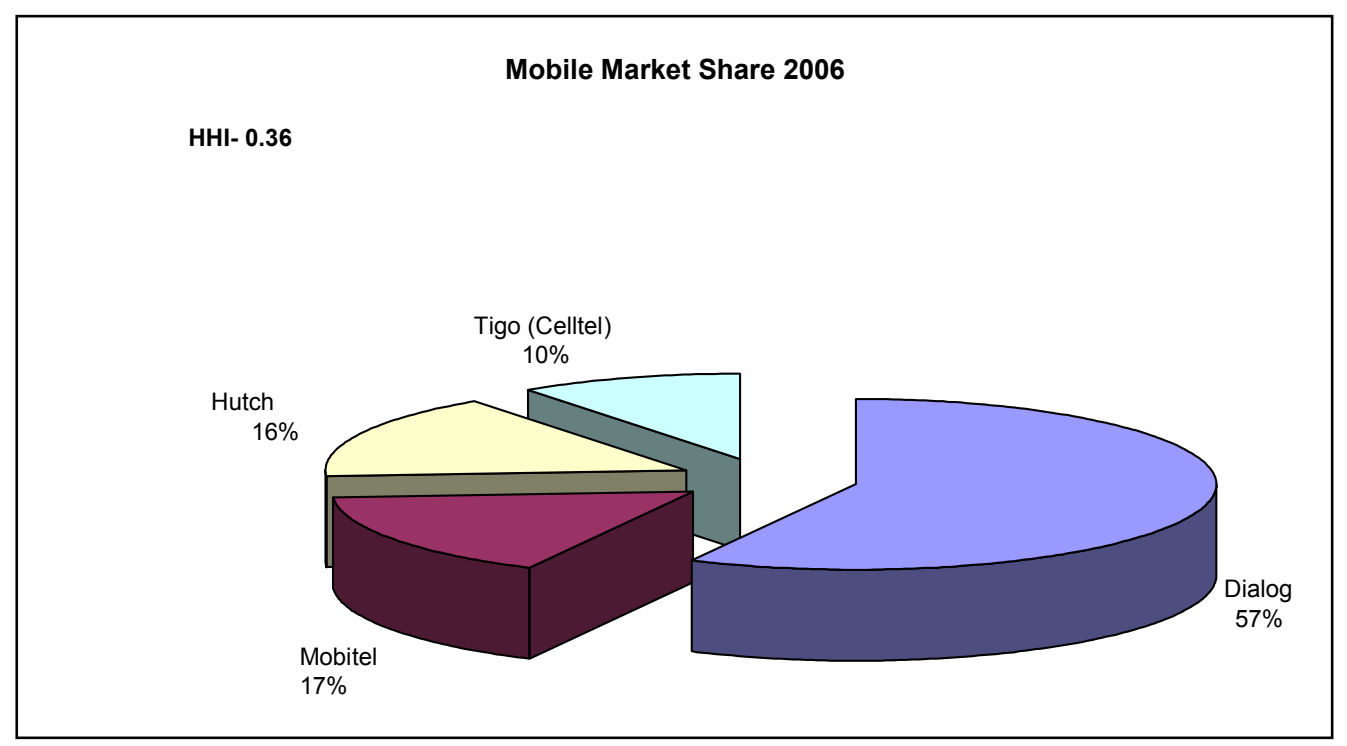

Note: Calculated based on subscriber numbers.

Source: Industry sources.

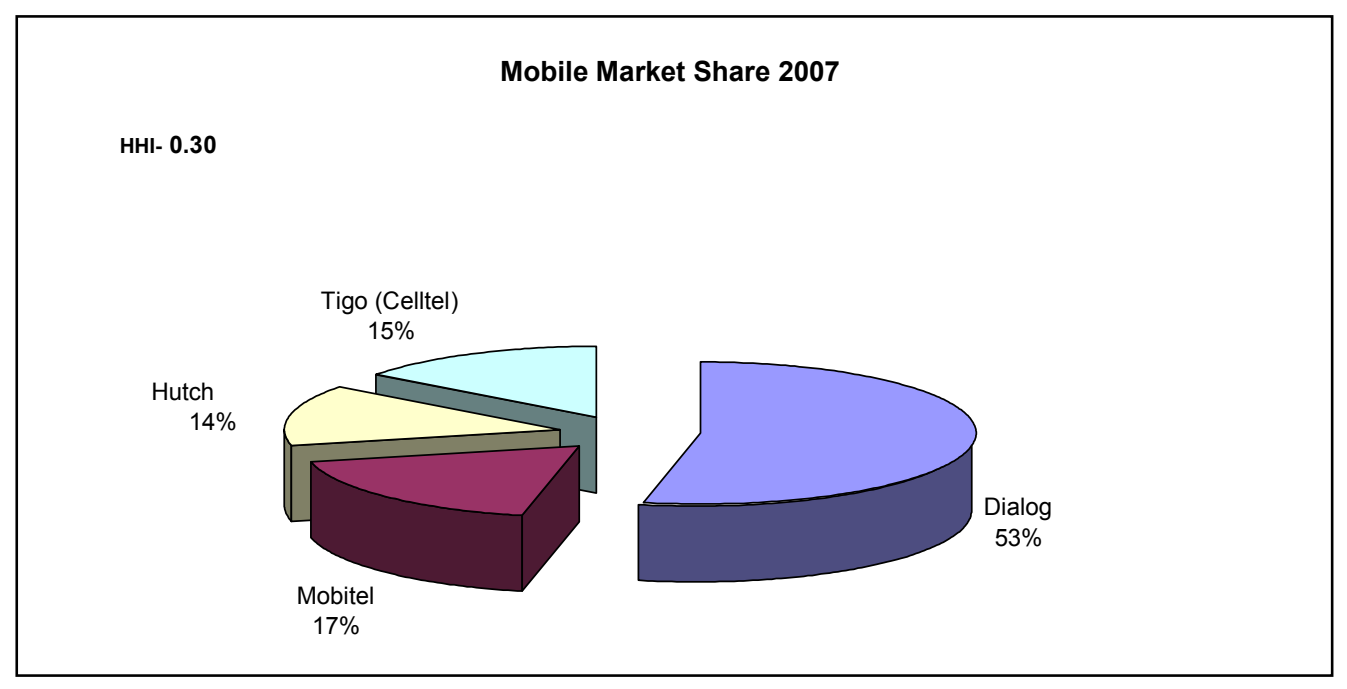

Note: Calculated based on subscriber numbers.

Source: Industry sources.

The development of Sri Lanka's telecom sector from one where it was a drain on public resources to one that is now one of the most important sub-sectors of the economy can be attributed to three key factors. First, early, pro-competitive reforms beginning in 1980 and continuing up to about the mid-late 1990s gave Sri Lanka an edge in terms of telecom sector performance - for instance, the outcome of the threat of contestability 
from the WLL operators from 1995 and the partial privatization of SLTL in 1997 is shown in fixed growth trends in Figure 1. Admittedly there were isolated instances of sensible regulatory and policy actions even after the mid-late 1990s such as the assigning of CDMA frequencies to all fixed operators in 2005 - the results of which are reflected in the growth spurt in the fixed sector shown in Figure 1 above. In addition, the growth momentum in both the fixed and mobile sector in the period between 2002-2005 was also a result of new business opportunities following the ceasefire of 2001 and the opening up of the Northern Province. Figure 1 also points to a steady upward growth trend line in the mobile sector in comparison to the fixed sector - again a reflection of the higher level of competition in the mobile sector (as is also seen in the mobile sector concentration ratios in Figure 4 above.)

Second, the liberalization of the sector facilitated the permeation of global technological practices- even bypassing obtuse regulations such as the previous ban on the use of VOIP by the TRC -with significant benefits to users; and third, competition amongst the sector operators has improved access and affordability- in spite of bad regulation such as the imposition of taxes on mobile phone users in September 2007, on CDMA phone users in April 2008 and more recently on fixed line users in the Budget proposals for 2009. Whilst it can be argued that progress has been made on the policy front by making the telecom tax technology neutral, the question remains as to the long-term rationality of taxing a sector that as pointed out in Table 3 above is already amongst the top contributors to the Treasury.

The imposition of telecom-specific taxes combined with the tripling of spectrum charges and macroeconomic factors such as rising inflation and high interest rates appear to already have had an impact on players such as Dialog - which has reported a loss of 192.4 million rupees for the September 2008 quarter, largely due to hemorrhages in its pay TV segment; and, Hutch - which has also reported a fall in profits and revenue growth. Moreover, research by LIRNEasia - (see for instance, de Silva and Zainudeen, 2008) shows that access to telecom services have a significant impact on users at the 
BOP; in the event that telecom taxes impact on affordability it is these poorest users that will be affected the most.

\section{Results and Analysis of the TRE Survey for Sri Lanka}

\subsection{Overall Scores}

Figure 5: Overall TRE scores for 2008

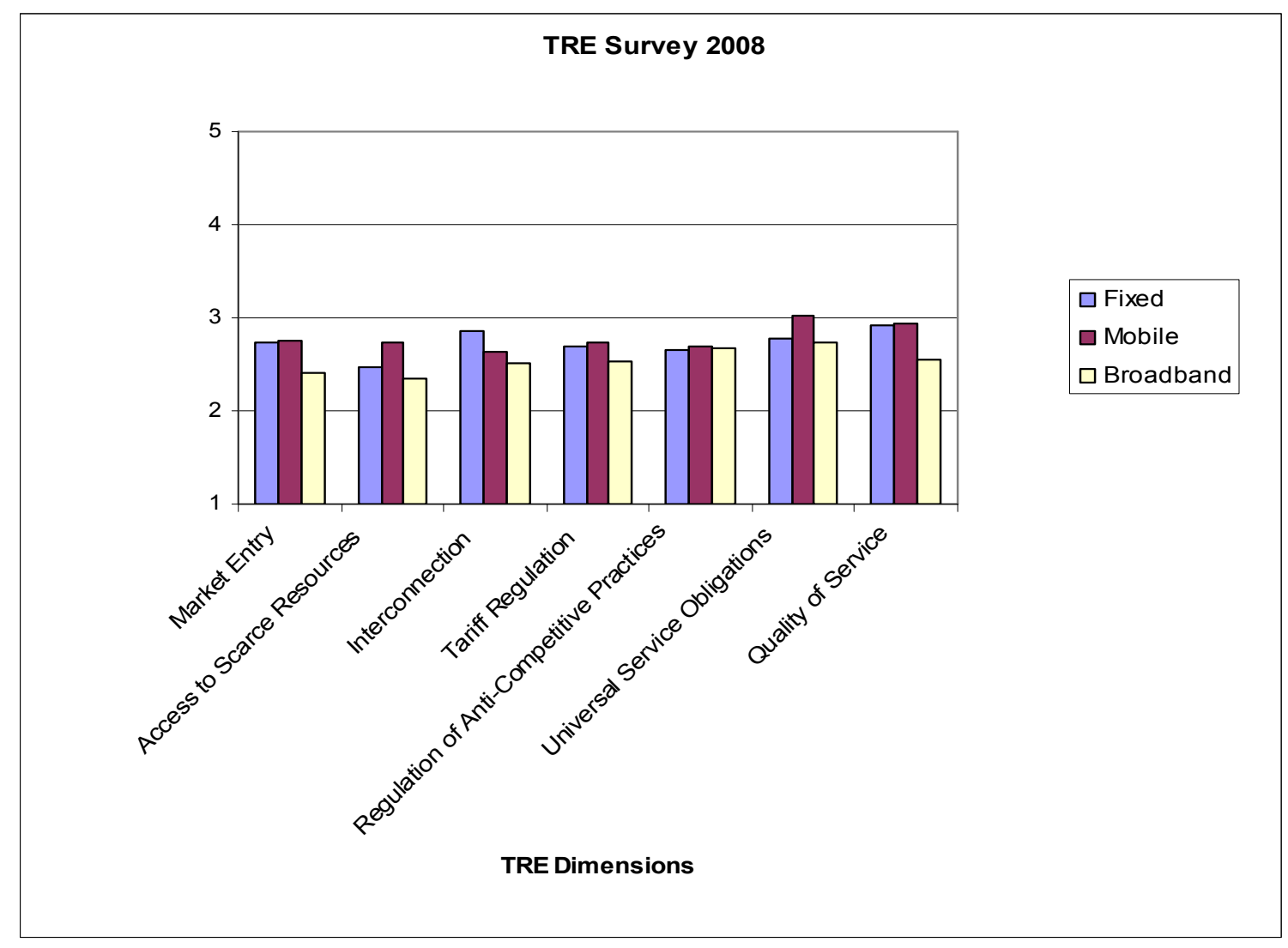

The results of the 2008 TRE survey, as depicted in Figure 5, show that the mobile sector receives higher scores than the fixed sector for all dimensions excepting interconnection. In addition, the broadband sector lags behind both the fixed and mobile sectors in all but one of the parameters (regulation of anti-competitive practices). What also emerges in the results illustrated above is that all the sectors - other than mobile sector USOs - fall below the 3.00 average performance level.

Table 5 below compares the average scores for each parameter for the fixed and mobile sectors coming out of the TRE survey for 2008 with those of the 2006 survey. Given that 
QoS was not included as a parameter in the 2006 questionnaire, this dimension is not included in the comparison set out below; the broadband sub-sector that was not a part of the TRE survey for 2006-2007 is also not included in this comparison. The key facts that emerge from the comparison contained in Table 5 is that overall TRE scores have improved marginally in both the fixed and mobile sectors between the 2005-2006 period and the 2007-2007 period; scores for market entry in the mobile sector have dropped from 3.1 to 2.8; scores for fixed sector interconnection have increased from 2.3 to 2.9; and, scores for USOs in both sectors have recorded increases.

Table 5: Comparing the average TRE scores for 2005-2006 and 2007-2008

\begin{tabular}{|l|c|c|c|c|}
\hline TRE parameter & \multicolumn{2}{|c|}{ Fixed } & \multicolumn{2}{c|}{ Mobile } \\
\hline & $\mathbf{2 0 0 5 - 2 0 0 6}$ & $\mathbf{2 0 0 7 - 2 0 0 8}$ & $\mathbf{2 0 0 5 - 2 0 0 6}$ & $\mathbf{2 0 0 7 - 2 0 0 8}$ \\
\hline Market entry & 2.7 & 2.7 & 3.1 & 2.8 \\
\hline Access to scarce resources & 2.5 & 2.5 & 2.8 & 2.7 \\
\hline Interconnection & 2.3 & 2.9 & 2.4 & 2.6 \\
\hline Tariff regulation & 2.7 & 2.7 & 2.9 & 2.7 \\
\hline Anti-competitive practices & 2.4 & 2.7 & 2.6 & 2.7 \\
\hline USOs & 2.5 & 2.8 & 2.6 & 3.0 \\
\hline Overall & $\mathbf{2 . 5}$ & $\mathbf{2 . 7}$ & $\mathbf{2 . 7}$ & $\mathbf{2 . 8}$ \\
\hline
\end{tabular}

These scores are analyzed in detail - in the context of the policy and regulatory developments and market dynamics in the telecom sector highlighted in Section 3 - in the rest of this Section.

\subsection{Market Entry}

The TRE questionnaire for 2008 (contained in Annex 2), defines the scope of market entry largely in terms of the transparency of licensing and licensing conditions. As illustrated in Figure 6, the scores for all three sectors - fixed, mobile and broadband indicate below average performance. What is more interesting however is the picture that emerges in Figure 7 - which compares market entry scores for 2006 and 2008 indicating a significant drop in the scores pertaining to the mobile sector (3.1 to 2.8). 
Figure 6: TRE scores for market entry: 2008

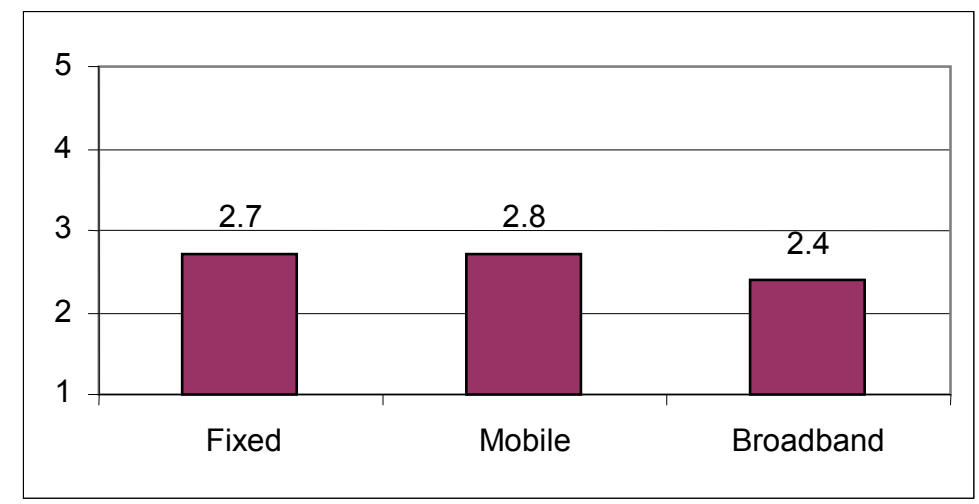

Figure 7: TRE scores for market entry: 2006 vs. 2008

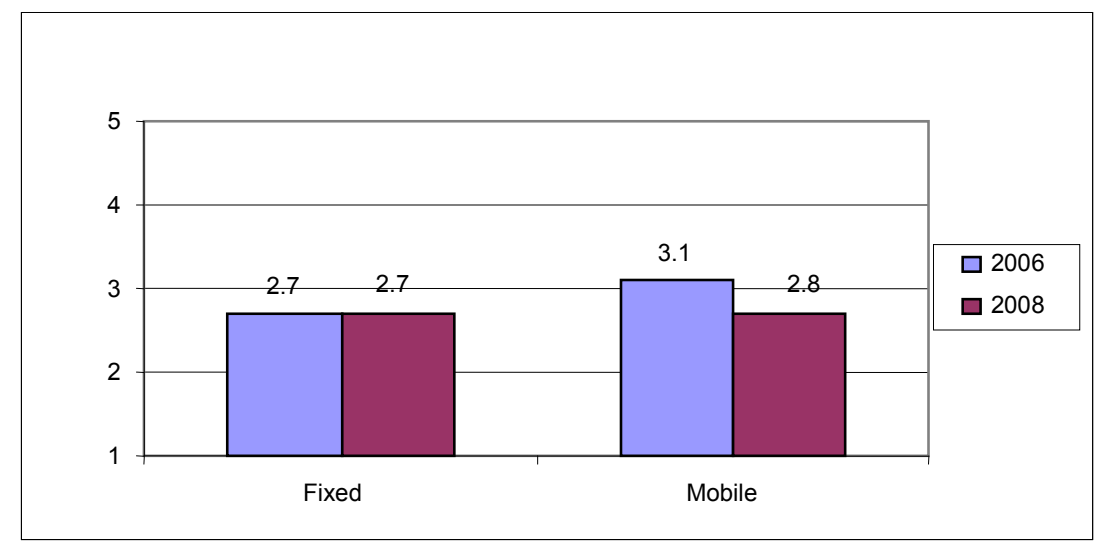

We argue that the drop in mobile sector TRE scores between 2006 and 2008 is a result of specific regulatory actions described in Table 2 above. First, the non-transparent process by which the USD 4 million Bharti Airtel license was issued by the TRC in 2007, contrary to Sri Lanka's commitment to the GATS Reference Paper that specifies the public availability of licensing criteria. Second, the questionable manner in which WiMax licenses were issued in 2007, with the terms and conditions of individual licenses (including the specific reasons for denial of a license) not being made publicly available. For instance, whilst Dialog obtained a WiMax license in 2007, SLTL announced in May 2008 that it had decided to purchase stakes in Sky Network - a unit of UK's Lycatel group, to expand its broadband service network, due to inordinate delays (without specific reasons being cited) in obtaining a WiMax license from the TRC. 


\subsection{Access to scarce resources}

An analysis of the TRE questionnaire responses that we received suggests that a majority of the respondents perceived access to scarce resources in terms of spectrum/frequency allocation and rights of way. As shown in Figure 8, all three sub-sectors show dismal performance in this category - as also indicated in Table 5 above, the 2008 TRE scores for scarce resources in the fixed sector is the lowest amongst the seven parameters.

Figure 8: TRE scores for scarce resources: 2008

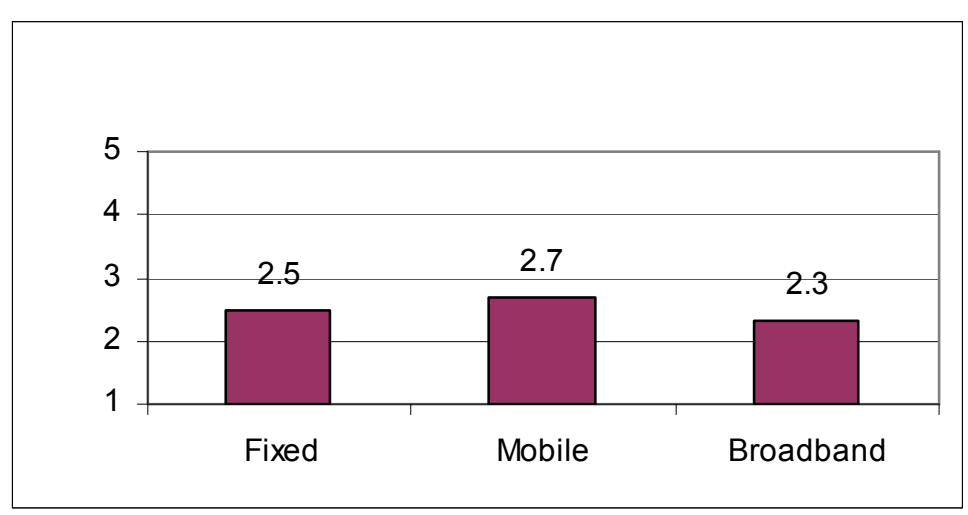


Figure 9: TRE scores for access to scarce resources: 2006 vs. 2008

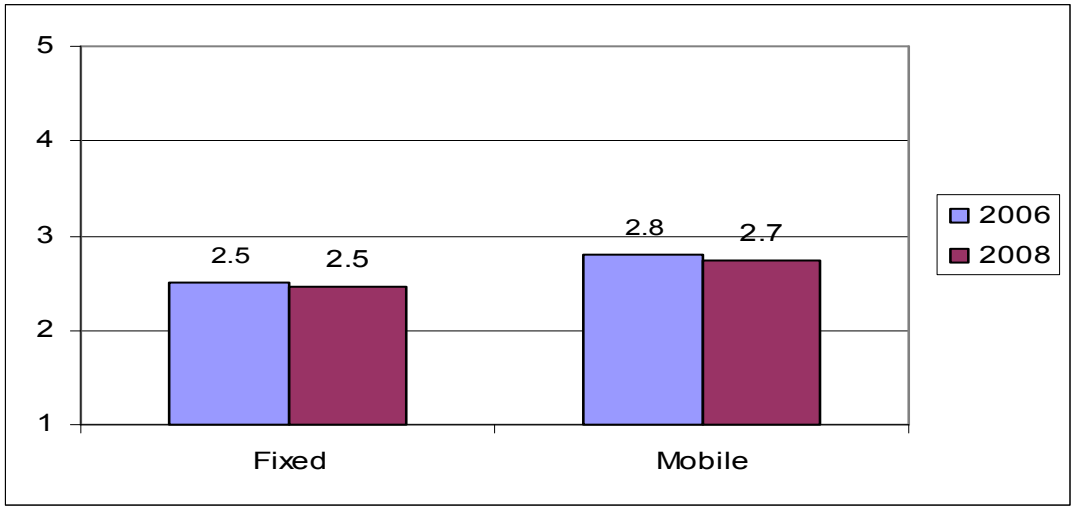

As per Sri Lanka's commitment to the GATS Reference Paper, procedures for the allocation and use of scarce resources such as frequencies and rights of way have to be carried out in an objective, timely, transparent and non-discriminatory manner. However, these procedures still remain opaque in Sri Lanka; relatively simple exercises such as updating the Master Frequency Register published by TRC in 2003 are neglected - for instance, the CDMA frequency allocations of 2005 are not recorded in this Register even at the time of writing. Moreover spectrum allocation and refarming is done administratively on a relatively ad hoc basis - as opposed to a more transparent and methodical approach such as auctions (the one exception was the assignment of the 1800 GSM frequencies in 2003).

A key issue in terms of rights of way that may well explain the low TRE scores for the access to scarce resources parameter, is the fact that SLTL has exclusive access to the nation-wide optic fiber network (see Annex 6). As at the time of writing, there has been no regulatory or policy initiative to derive a cost-effective solution for other operators to access this backbone; infrastructure sharing is not mandated by the TRC. An example of market solutions that bypass regulatory inaction is reflected in the case of the Lanka Bell purchase of the FLAG global undersea cable - which effectively ended SLTL's exclusive hold in this segment.

\subsection{Interconnection}

The key elements contained in the TRE survey questionnaire on interconnection included the following: interconnection with a major operator being ensured at any technically 
feasible point in the network; quality of interconnection comparable to similar services offered by own network; and, reasonable rates for interconnection. The TRE scores for 2008 shown in Figure 10 indicate that all three sub-sectors perform below average in terms of this parameter - although fixed sector scores are relatively higher than those of the other two sectors. A comparison of the two survey periods in Figure 11 below indicates that both the fixed and the mobile sectors score higher in 2008 in comparison to 2006.

Figure 10: TRE scores for interconnection: 2008

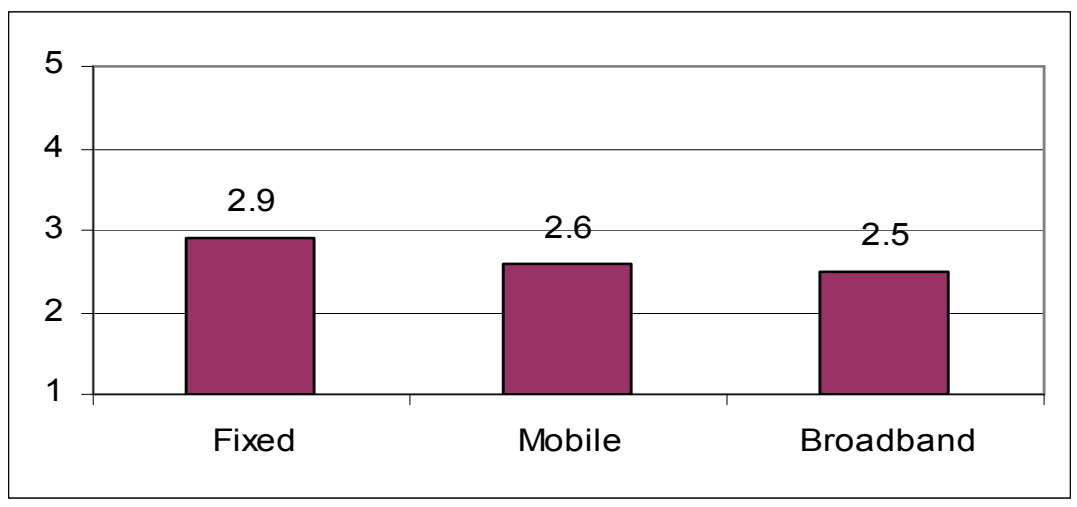

Figure 11: TRE scores for interconnection: 2006 vs. 2008

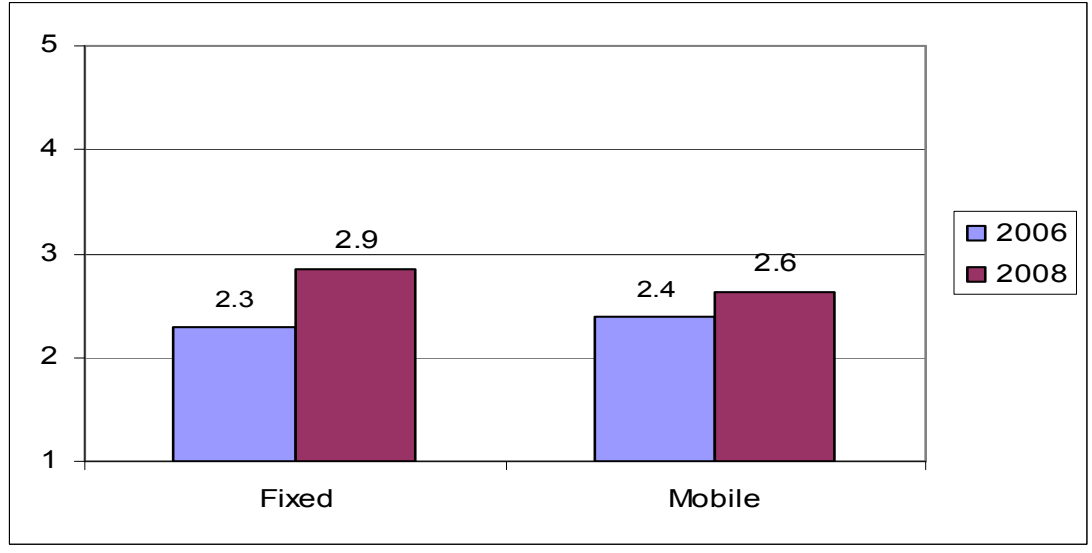

The relatively lower scores for mobile sector interconnection in 2008 is possibly a reflection of the interconnection imbroglio surrounding the entry of Bharti Airtel, with this fifth mobile operator issuing press statements to the effect that its entry into the market was blocked by the fact that all existing operators (with the exception of SLTL) had not responded to its request for interconnection in August 2007. More recent market 
information from stakeholders in the market, indicate that Bharti Airtel has reached an agreement with Lanka Bell to use its previous allocated numbers (beginning with the prefix 075) and is set to launch formal operations in March 2009. (However, these recent developments are obviously not reflected in the TRE results for 2008.)

More generally, interconnection remains a significant problem in the telecom sector despite the gazetting of Interconnection Rules in March 2003 in line with commitments to the GATS Reference Paper (Dharmawardena, 2004). The TRC has failed to implement these Rules effectively - as seen in for instance in the interconnection issues faced by the EGOs highlighted in Table 2 above; in the Bharti Airtel case; and, in the discriminatory stance with respect to interconnection rates - with mobile operators providing free termination services to fixed operators (cross-subsidizing these from origination services) and fixed operators effectively getting a free ride on mobile networks (paying termination fees only to other fixed operators and not to mobile operators).

This informal free-riding arrangement between the fixed operators could perhaps be the reason for the higher 2008 TRE scores that this sector shows in comparison to the mobile sector. However, the improved scores for both sectors between the two survey periods remains puzzling - and does run contrary to (bad/ineffective) policy and regulatory actions on interconnection.

\subsection{Tariff Regulation}

The TRE survey questionnaire defined this parameter as the regulation of tariffs charged from consumers. As per Section 5 (C) of Sri Lanka Telecommunications Act No. 25 of 1991, as amended by the Sri Lanka Telecommunications (Amendment) Act No. 27 of 1996, the TRC has the powers to advise the GOSL on matters relating to telecommunications including policies on tariffs, pricing and subsidies. 
Figure 12: TRE scores for tariff regulation: 2008

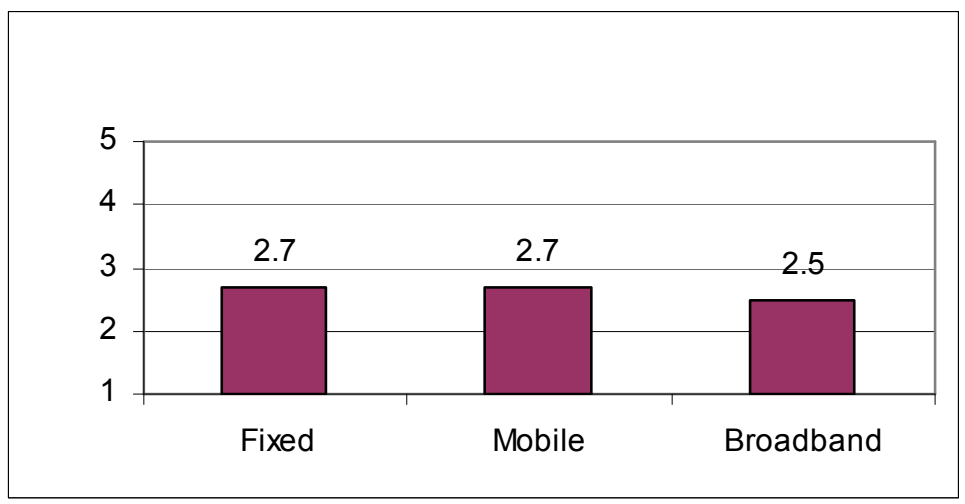

Figure 12 illustrates that there is no discrepancy between the 2008 TRE scores for the fixed and mobile sectors; however, the broadband sector shows much lower scores. The low scores for the broadband sector pose a conundrum - particularly given the data released by LIRNEasia and set out in Section 3 above indicating that Sri Lanka's broadband prices are amongst the lowest in the South Asian region.

Figure 13: TRE scores for tariff regulation: 2006 vs. 2008

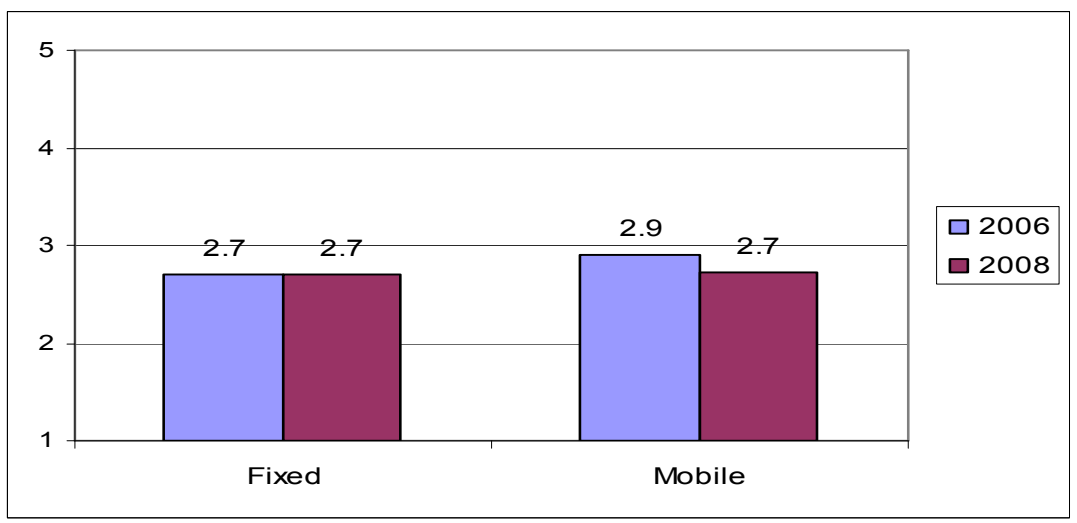

Figure 13 shows a comparison of TRE scores with respect to tariff regulation between the two survey periods. What is somewhat puzzling, is the drop in the TRE scores for mobile sector tariff regulation between 2006 and 2008 - particularly, in the context of the dropping of prices by Mobitel followed by Dialog and Tigo's action to make all incoming calls free. 
As per our interviews with industry stakeholders, the TRC does not in general intervene in the tariff packages and pricing strategies adopted by mobile operators (although it has the authority to advise the GOSL on tariffs as per the law). It is highly unlikely that this hand-off approach adopted by the TRC, which has largely been the practice in any case in the past with respect to the mobile sector, has any bearing on the lower 2008 TRE scores for mobile tariff regulation - implying a gap between regulatory and policy actions and the TRE data.

Even if market dynamics - as opposed to regulatory and policy actions - were to explain the TRE scores for this parameter, the dropping of prices in the mobile sector in 2008 would indicate a higher score between the two survey periods. As such, our analysis in the case of this parameter can only conclude that no meaningful explanation can be derived with respect to the fall in mobile sector TRE scores for this parameter either in terms of regulatory and policy actions or in the context of market dynamics.

\subsection{Regulation of anti-competitive practices}

The TRE questionnaire used for this survey included elements such as anti-competitive cross-subsidization, excessive prices, price discrimination and predatory pricing, refusal to deal with other operators and the sharing of towers and facilities by a parent company and subsidiaries in different segments of the market. The TRE scores for 2008 shown in Figure 14 below indicate below average performance in all three sectors. A possible reason for the below average performance - which is reflected in the telecom environment for anti-competitive practices per se - could well be the much publicized Airtel story where as mentioned above, most of the operators did not respond to this company's request for interconnection. 
Figure 14: TRE scores for anti-competitive practices: 2008

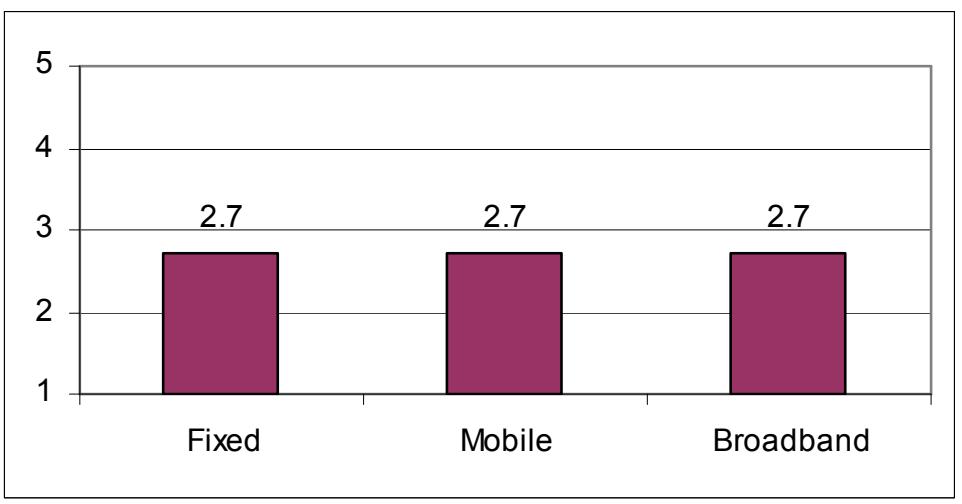

Although the price war in the mobile sector is not an instance of predatory pricing as per the standard economic definition that describes this strategy as one carried out by a dominant firm to drive competitors out of the market by setting prices below average variable costs with the intention of raising prices and earning profits at a later time period once competitors have been driven out of the market or deterred from entering the market, comments from respondents did suggest that the price war (which we see as an exercise of competition) was viewed by several stakeholders as anti-competitive behavior.

Interestingly, the comparative scores for 2006 and 2008 shown in Figure 15 below indicate an improvement in both the fixed and the mobile sectors in terms of anticompetitive practices. Apparently, practices such as the sharing of facilities and crosssubsidization (although admittedly not definitively proven due to data gaps both at the TRC and in the figures published in the Company Annual Reports) in the SLTL group (SLTL and Mobitel) and the Dialog group (Dialog Telekom, Dialog Broadband, Asset Media) are not captured in stakeholder perceptions. 
Figure 15: TRE scores for anti-competitive practices: 2006 vs. 2008

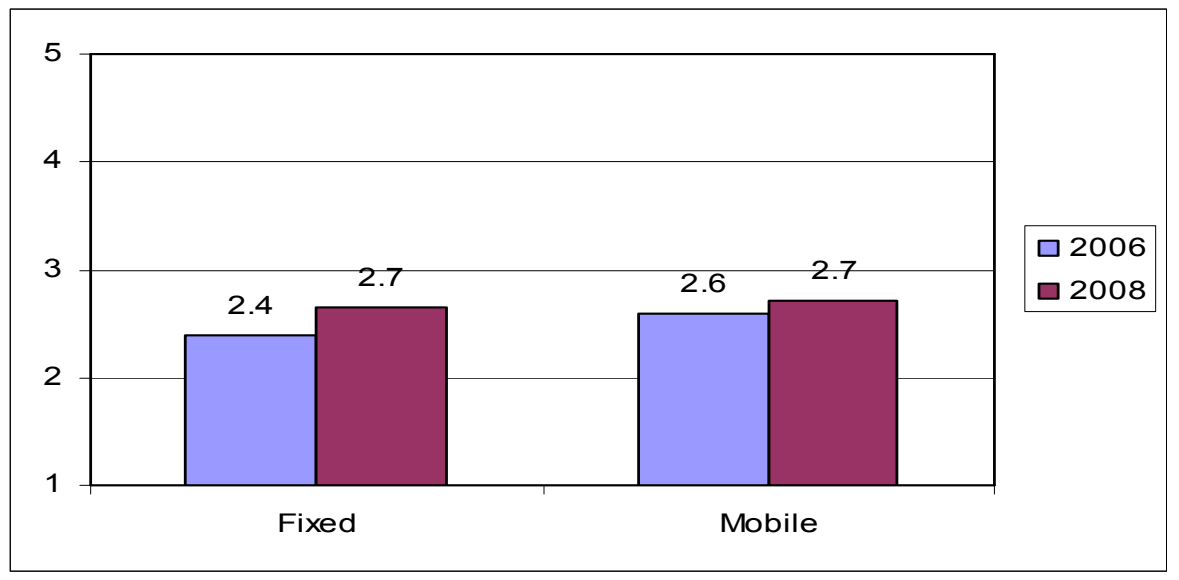

\subsection{USOS}

The key element defining the regulation of USOs as per the TRE questionnaire was the administration of the USO fund in a transparent, non-discriminatory and competitively neutral manner. As illustrated in Figures 16 and 17 and as is pointed out in Table 5 above, this category performs relatively well in all three sectors, with mobile sector scores recording above average performance in 2008 and both the fixed and mobile sectors showing improved scores between the two survey periods.

Figure 16: TRE scores for USOs : 2008

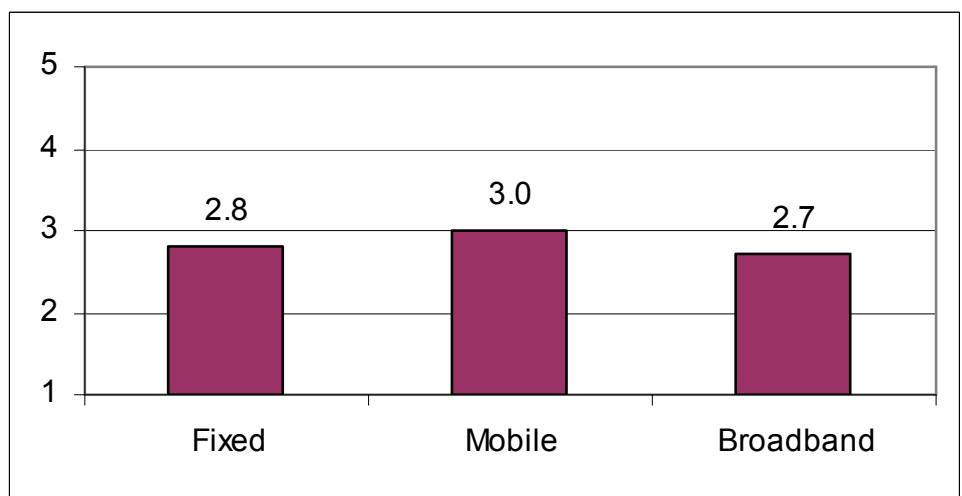


Figure 17: TRE scores for USOs: 2006 vs. 2008

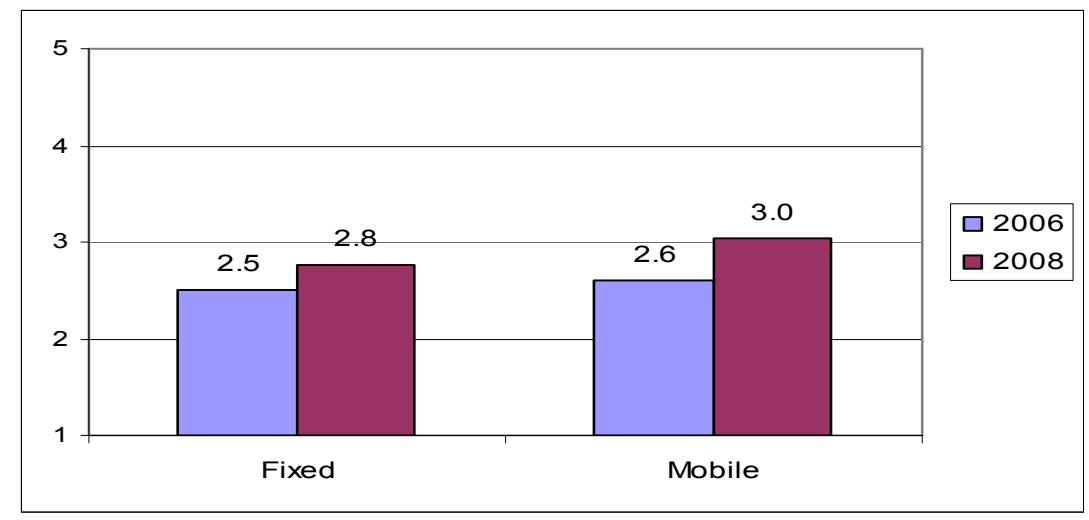

\section{Whilst USOs were defined in the context of the administration of the USO fund in the TRE questionnaire, an analysis of the survey responses suggests that respondents answered this question in the context of access to services. Given the growth and expansion of telecom sector services described in Section 3 above therefore, the high TRE scores for USOs do not come as a surprise.}

What is worrisome in this regard however, is the fact that a majority of the respondents despite being informed stakeholders - were not aware of the details of Sri Lanka's USO fund. The practice in Sri Lanka since 2003, as gazetted by the GOSL, has been to use levies on international calls for the USO fund; a third of the income earned from a 1 minute international call (0.9 USD) is to be allocated for the fund. In view of the fact that this fund has been in place since 2003 and that the number of international traffic minutes has grown enormously since then, the fund is estimated (by industry analysts that do have information on the fund) to amount to billions of rupees. As per the gazette pertaining to the USO fund, these monies were to be re-distributed amongst operators as they achieved universal service targets set out in their licenses - for instance a particular number of connections in rural locations. As at the time of writing however, the USO fund has not been disbursed - with industry sources citing suspicions that these monies are being utilized for fiscal purposes rather than for the improvement of universal access.

\subsection{QoS}

The principal feature defining QoS in the survey questionnaire was the actual performance of a service with respect to what is promised. As shown in Figure 18 below, 
the TRE scores for the fixed and mobile sectors indicate relatively good performance (although marginally below the half-way mark) in this parameter. However, the broadband sector lags behind both the other sectors. We attribute the lower performance in QoS in the broadband sector to the gaps between advertized and actual speeds highlighted in Section 3 above.

Figure 18: TRE scores for QoS: 2008

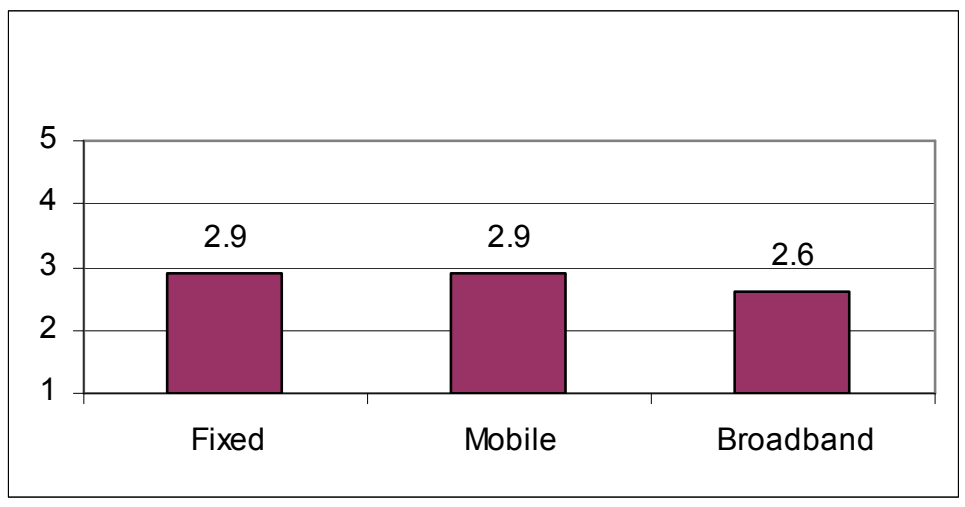

\section{Conclusions and Recommendations}

The analysis contained in Sections three and four of this report leads to three key conclusions. First, growth and service expansion in the telecom sector and its evolution over the years to become one of the leading contributors to GDP and government revenue is for the most part a result of competitive actions by operators in spite of bad regulation and policy. Second, developments in the regulatory environment suggest that Sri Lanka has failed to live up to several of its commitments under the GATS Reference Paper leaving the country open to legal cases with respect to violations of international treaty commitments. Third, from a methodological point of view, the TRE scores - both individually for 2008 and when comparing the 2006 and 2008 numbers - are not entirely reflective of developments in the telecom sector.

However, our research leads us to several key policy recommendations with respect to the telecom sector. First, given that improvements in the sector have largely been a result of competition and liberalization - as argued also in Section 3 above - the TRC needs to follow the basic principles of regulating only when necessary and regulating for 
competition. Following from this tenet we argue that areas such as tariff regulation and QoS be left to the market forces of consumer choice and revealed preference.

Second, policy makers need to place the effective implementation of the GATS Reference Paper as a top priority in their agenda -a necessary action which has been lacking across successive policy regimes. This includes the following regulatory actions:

- Enforcing transparent licensing procedures

- Moving from an ad hoc administration of spectrum to auctions - which are a more transparent means of allocating and refarming frequencies and reducing the opportunities for rents

- Putting in place a cost-effective access sharing mechanism that would enable operators to share essential facilities such as the national backbone infrastructure

Third, Sri Lanka lacks an effective competition regime. Currently, anti-competitive practices in the telecom sector are governed by way of concurrent jurisdiction through two institutions - TRC and CAA. However, in effect, both these entities lack expertise on anti-competitive practices (with CAA for instance, focusing solely in recent months on curbing the prices of essential goods - based on a political agenda linked to the pre-election Budget of 2009). A solution in such instances would be to embed competition rules - such as for instance provisions with respect to the preferential treatment of Mobitel by SLTL with respect to access to essential facilities - in licenses.

Policy recommendations aside - and this applies across the board to all sectors and not merely the telecom sector - Sri Lanka has in general displayed a significant gap between policy rhetoric and actual implementation due to lapses in governance. In the final instance therefore, what actually gets implemented depends on interest group and stakeholder dynamics - and in particular political buy-in at the top levels of government. 


\section{Acknowledgements}

The author gratefully acknowledges the valuable assistance provided by Dilani Hirimuthugodage, Indika Siriwardena and Romali Tudawe in administering the TRE survey for 2008 and in collecting and compiling telecom indicator data. The co-operation and participation of key stakeholders in the telecom policy space, in the TRE survey for 2008 is greatly appreciated. The support provided by Dimuthu Ratnadiwakara at LIRNEasia in conducting the TRE survey on-line is acknowledged. The author also thanks Rohan Samarajiva and Helani Galpaya of LIRNEasia for the substantive comments on previous versions of this paper.

This research is conducted as part of LIRNEasia's Telecom Regulatory Environment Survey. Research funding was provided by the International Development Research Center, Canada. 


\section{References}

Central Bank of Sri Lanka. (various years) Annual Report. Colombo: Central Bank.

Department of Census and Statistics. Household Income and Expenditure Survey: 2006/2007. Colombo: Department of Census and Statistics.

Department of Census and Statistics. Household Income and Expenditure Survey: 2003/2004. Colombo: Department of Census and Statistics.

De Silva, H, and A. Zainudeen. (2008) "Teleuse at the Bottom of the Pyramid: Beyond Universal Access" available at: http:/www.telenor.com/telektronikk/volumes/ pdf/2.2008/Tel_2-08_Page 025-038.pdf

Dharmawardena, S. (2004). "Sri Lanka's experience in interconnection and liberalization of the international telecom segment", in SAFIR Newsletter Issue 15, p.2-7, February 2004, TERI, New Delhi

Dialog Telekom Ltd. (various years) Annual Reports. Colombo: Dialog Telekom Ltd.

Hanna, Nagy, K. (2007) From Envisioning to Designing e-Development: The Experience of Sri Lanka. Washington D.C.: The World Bank.

Jayasuriya S, M. Knight -John M. (2002), Sri Lanka's Telecommunication Industry: From Privatization to Anti-Competition?, Working Paper No; 14, Manchester: Center on Regulation and Competition

Knight -John M. (2007). "Telecommunication Sector and Regulatory Performance in Sri Lanka: A Tale of Missed Opportunities?" available at: www.lirneasia.net/wpcontent/uploads/2008/05/knight-john-2007-6cmcs-sri-lanka.pdf

Ministry of Finance and Planning. Fiscal Management Report 2007. Colombo: Ministry of Finance and Planning

Ministry of Finance and Planning. Fiscal Management Report 2008. Colombo: Ministry of Finance and Planning

Samarajiva, R. and A.Dokeniya (2003). Regulation and Investment: Sri Lanka Case Study. World Dialog on Regulation, Discussion Paper 0303b, available at: http://www.regulateonline.org/content/view/207/31

Samarajiva, R. (2004). “Sri Lanka's Telecom Reforms of 2002/03” in SAFIR Newsletter Issue 17, p.5, August 2004, TERI, New Delhi

Samarajiva, R, H. Galpaya and D. Ratnadiwakara (2007) “Telecom Regulatory Environment (TRE) assessment: Methodology and implementation results from five emerging economies" available at : www.scribd.com/doc/2799021/SamarajivaGalpaya $\underline{\text { Ratnadiwakara-TPRC }}$ 
Samarajiva, R. (2007.) "Adherence to international law in telecom: Why Sri Lanka should live up to its promises at least", Paper presented at the National Law Conference 2007, October $28^{\text {th }} 2007$

Samarajiva, R. and A.Zainudeen (eds.) (2008) ICT Infrastructure in Emerging Asia: Policy and Regulatory Roadblocks. India: Sage Publications.

Sri Lanka Telecommunications Act No. 25 of 1991 as amended by Sri Lanka Telecommunications (Amendment) Act No. 27 of 1996, available at: http://:www.trc.gov.lk

Sri Lanka Telecom Ltd. (various years). Annual Reports. Colombo: SLTL.

World Trade Organization. (1997). "Schedule of Specific Commitments of Sri Lanka" WTO Reference Paper, available at: http://tsdb.wto.org/wto/

World Trade Organization. (1997). "Telecommunications Reference Paper" available at: http://www.wto.org/english/tratop_e/serv_e/telecom_e/tel23_e.html

Zainudeen, A., N. Sivapragasam, H. de Silva and T. Iqbal (2007). "Teleuse at the Bottom of the Pyramid: Findings from a Five-Country Study”. Colombo: LIRNEasia 


\section{ANNEXURES}

Annex 1: Fact sheet of key events in the telecom regulatory environment in Sri Lanka: May 2007-May 2008

\begin{tabular}{|c|c|}
\hline Date & Event \\
\hline May 2007 & $\begin{array}{l}\text { The TRC grants permission to } 8 \text { PSTN operators to appoint a third } \\
\text { party to operate and maintain a public phone booth on a revenue } \\
\text { sharing model. }\end{array}$ \\
\hline September 2007 & $\begin{array}{l}\text { A new tax imposed on mobile users by the Finance Ministry. A } 10 \\
\text { percent tax on all call charges was introduced in place of a } 2.5 \\
\text { percent tax and the Rs. } 50 \text { monthly fixed tax was removed. }\end{array}$ \\
\hline November 2007 & $\begin{array}{l}\text { TRC invites telecom operators to submit their requests and } \\
\text { suggestions to remove technological limitations and allow them to } \\
\text { share network resources to further liberalize the market. }\end{array}$ \\
\hline January 2008 & $\begin{array}{l}\text { Sri Lanka Ministry of Transport gives approval to TRC to select } \\
\text { telecom operators to lease the country's } 1200 \mathrm{~km} \text { rail track, after a } \\
\text { study jointly conducted by the Ministry of Transport and the TRC. }\end{array}$ \\
\hline April $1^{\text {st }} 2008$ & $\begin{array}{l}\text { A new tax imposed on CDMA phones by the Finance Ministry. Tax } \\
\text { rate increased to } 10 \text { percent on call charges from the previous } 2.5 \\
\text { percent. }\end{array}$ \\
\hline April $4^{\text {th }} 2008$ & $\begin{array}{l}\text { TRC invites project proposals from the licensed ISPs to establish } \\
\text { their own links for last mile access using wireless technologies } \\
\text { operating in the } 5.4 \mathrm{GHz} \text { and } 5.7 \mathrm{GHz} \text { bands on a shared basis. }\end{array}$ \\
\hline April $4^{\text {th }} 2008$ & $\begin{array}{l}\text { TRC publishes a consultation paper on "Planning and } \\
\text { Implementation of National Fiber Backbone Network". }\end{array}$ \\
\hline May 2008 & $\begin{array}{l}\text { TRC invites applications from entrepreneurs interested in obtaining } \\
\text { a license to provide non-voice telephony services using cable } \\
\text { distribution networks and satellite communication networks. }\end{array}$ \\
\hline
\end{tabular}




\section{Annex 2: TRE Questionnaire}

Questionnaire Number:

\section{Telecom Regulatory Environment for Sri Lanka}

You are kindly requested to make your frank assessments of the telecom regulatory environment (TRE) for the year 12 months ending May,2008 for the fixed, mobile and broadband telecom sectors on a five-point scale.

The dimensions used in this questionnaire are broadly based on the WTO Regulatory Reference Paper (GATS Protocol 4) and are briefly described below. A fact-sheet of key events in the Telecom Regulatory Environment is also attached for your reference for the period May 2007- May 2008.

Completing the Questionnaire should take less than 5 minutes of your time. Please email the completed questionnaire to dilani@ips.lk or fax it to 0112431395 . If you prefer, you can complete the same survey online.

\begin{tabular}{|c|c|}
\hline Dimension & Aspects Covered \\
\hline Market Entry & $\begin{array}{l}\text { Transparency of licensing. Applicants should know the terms, conditions, criteria } \\
\text { and length of time needed to reach a decision on their application. License } \\
\text { conditions. Exclusivity issues. }\end{array}$ \\
\hline Scarce Resources & $\begin{array}{l}\text { Timely, transparent and non-discriminatory access to spectrum allocation. } \\
\text { Numbering and rights of way: frequency allocation, telephone number allocation, } \\
\text { tower location rights. }\end{array}$ \\
\hline Interconnection & $\begin{array}{l}\text { Interconnection with a major operator should be ensured at any technically } \\
\text { feasible point in the network. Quality of interconnection comparable to similar } \\
\text { services offered by own network. Reasonable rates for interconnection. } \\
\text { Unbundling of interconnection. Interconnection offered without delay. Sharing of } \\
\text { incoming and outgoing IDD revenue. Payment for cost of interconnection links } \\
\text { and switch interface. Payment for cost of technical disruption of interconnection. }\end{array}$ \\
\hline Tariff Regulation & Regulation of tariffs charged from consumers. \\
\hline $\begin{array}{l}\text { Regulation of Anti } \\
\text { Competitive } \\
\text { Practices }\end{array}$ & $\begin{array}{l}\text { Anti-competitive cross subsidization. Using information obtained from } \\
\text { competitors with anti-competitive results. Not making technical information about } \\
\text { essential facilities and commercially relevant information available to competitors } \\
\text { on a timely basis. Excessive prices. Price discrimination and predatory low } \\
\text { pricing. Refusal to deal with operators and other parties. Vertical restraints. } \\
\text { Technical disruption of interconnection. Sharing of towers and facilities by parent } \\
\text { company and subsidiaries in different segments of the market. }\end{array}$ \\
\hline $\begin{array}{l}\text { Universal Service } \\
\text { Obligation (USO) }\end{array}$ & $\begin{array}{l}\text { Administration of the universal service program/fund in a transparent, non- } \\
\text { discriminatory and competitively neutral manner and is not more burdensome than } \\
\text { necessary for the kind of universal service defined by the policymakers. }\end{array}$ \\
\hline $\begin{array}{l}\text { Quality of Service } \\
\text { (QoS) }\end{array}$ & $\begin{array}{l}\text { ct to what is promised, depending upon the } \\
\text { criteria may be call quality (for mobile and } \\
\text { adband) }\end{array}$ \\
\hline
\end{tabular}

FIXED SECTOR Telecom Regulatory Environment, for May, 2007 - May, 2008

Please TICK the number that best represents the quality of the regulatory environment for each dimension. The lower number represents Highly Ineffective and the higher number represents Highly Effective. If you feel you do not have sufficient information about a particular question, you may choose to leave it blank. 


\begin{tabular}{|lllll|}
\hline Market Entry & $\begin{array}{l}\text { Highly } \\
\text { ineffective }\end{array}$ & & $\begin{array}{l}\text { Highly } \\
\text { effective }\end{array}$ \\
& 1 & $\square$ & 2 & 4
\end{tabular}

F

2

\begin{tabular}{|llllll|}
\hline $\begin{array}{l}\text { Access to Scarce } \\
\text { Resources }\end{array}$ & $\begin{array}{l}\text { Highly } \\
\text { ineffective }\end{array}$ & & $\begin{array}{l}\text { Highly } \\
\text { effective }\end{array}$ \\
\hline
\end{tabular}

F

3

\begin{tabular}{|lllll|}
\hline Interconnection & $\begin{array}{l}\text { Highly } \\
\text { ineffective }\end{array}$ & 1
\end{tabular}

F

4

\begin{tabular}{|c|c|c|c|c|}
\hline Tariff Regulation & $\begin{array}{l}\text { Highly } \\
\text { ineffective }\end{array}$ & & & $\begin{array}{l}\text { Highly } \\
\text { effective }\end{array}$ \\
\hline & $1 \square$ & 3 & 4 & 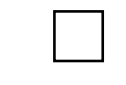 \\
\hline
\end{tabular}

F

5

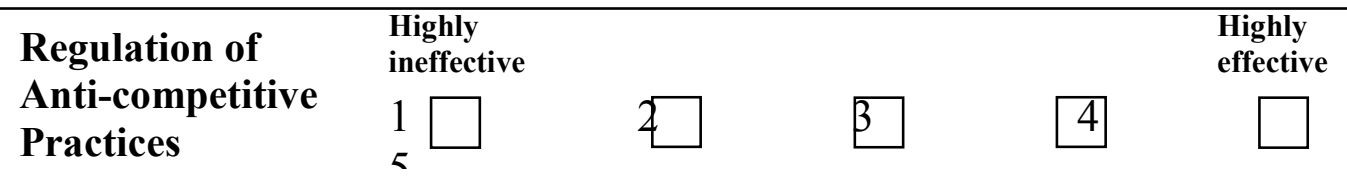




\begin{tabular}{|c|c|c|c|c|}
\hline Universal Service & $\begin{array}{l}\text { Highly } \\
\text { ineffective }\end{array}$ & & & $\begin{array}{l}\text { Highly } \\
\text { effective }\end{array}$ \\
\hline Obligation (USO) & 2 & $\beta$ & 4 & 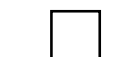 \\
\hline
\end{tabular}

$\mathrm{F}$

7

\begin{tabular}{|c|c|c|c|c|}
\hline Quality of Service & $\begin{array}{l}\text { Highly } \\
\text { ineffective }\end{array}$ & & & $\begin{array}{l}\text { Highly } \\
\text { effective }\end{array}$ \\
\hline (QoS) & 1 & $\beta$ & 4 & 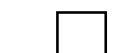 \\
\hline
\end{tabular}

\section{Comments:}

MOBILE SECTOR Telecom Regulatory Environment, for May, 2007- May, 2008

Please TICK the number that best represents the quality of the regulatory environment for each dimension. The lower number represents Highly Ineffective and the higher number represents Highly Effective. If you feel you do not have sufficient information about a particular question, you may choose to leave it blank.

M1

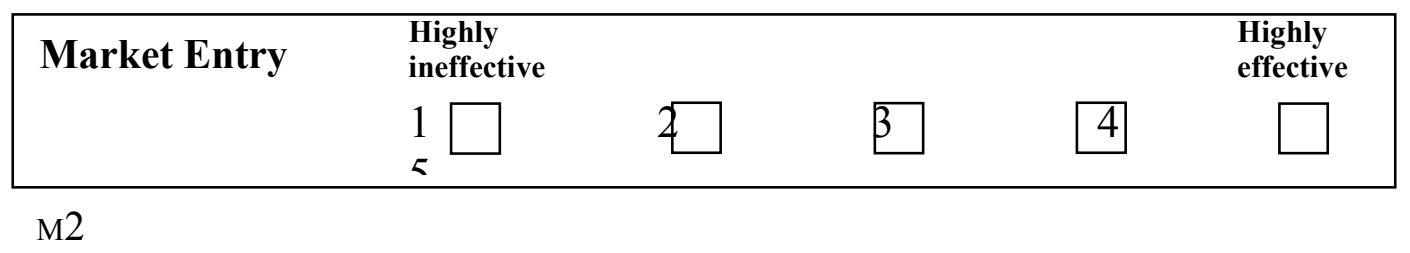

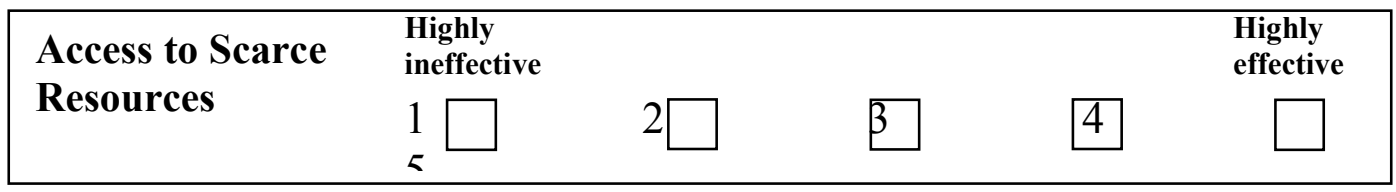




\begin{tabular}{|c|c|c|c|c|}
\hline Interconnection & $\begin{array}{l}\text { Highly } \\
\text { ineffective }\end{array}$ & & & $\begin{array}{l}\text { Highly } \\
\text { effective }\end{array}$ \\
\hline & 1 & 3 & 4 & $\square$ \\
\hline
\end{tabular}

M4

\begin{tabular}{|c|c|c|c|c|}
\hline Tariff Regulation & $\begin{array}{l}\text { Highly } \\
\text { ineffective }\end{array}$ & & & $\begin{array}{l}\text { Highly } \\
\text { effective }\end{array}$ \\
\hline & 1 & $\beta$ & 4 & 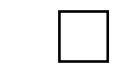 \\
\hline
\end{tabular}

M5

\begin{tabular}{|c|c|c|c|c|}
\hline Regulation of & $\begin{array}{l}\text { Highly } \\
\text { ineffective }\end{array}$ & & & $\begin{array}{l}\text { Highly } \\
\text { effective }\end{array}$ \\
\hline $\begin{array}{l}\text { Anti-competitive } \\
\text { Practices }\end{array}$ & 1 & $\sqrt{3}$ & 4 & \\
\hline
\end{tabular}

M6

\begin{tabular}{|c|c|c|c|c|}
\hline Universal Service & $\begin{array}{l}\text { Highly } \\
\text { ineffective }\end{array}$ & & & $\begin{array}{l}\text { Highly } \\
\text { effective }\end{array}$ \\
\hline Obligation (USO) & 2 & $\beta$ & 4 & 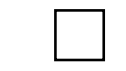 \\
\hline
\end{tabular}

\begin{tabular}{|c|c|c|c|c|}
\hline Quality of Service & $\begin{array}{l}\text { Highly } \\
\text { ineffective }\end{array}$ & & & $\begin{array}{l}\text { Highly } \\
\text { effective }\end{array}$ \\
\hline (QoS) & 1 & $\beta$ & 4 & \\
\hline
\end{tabular}


BROADBAND SECTOR Telecom Regulatory Environment, for May, 2007-May, 2008 (Broadband $=$ greater than $256 \mathrm{kbps}$ upload $/$ download)

Please TICK the number that best represents the quality of the regulatory environment for each dimension. The lower number represents Highly Ineffective and the higher number represents Highly Effective. If you feel you do not have sufficient information about a particular question, you may choose to leave it blank.

B

1

\begin{tabular}{|c|c|c|c|c|}
\hline Market Entry & $\begin{array}{l}\text { Highly } \\
\text { ineffective }\end{array}$ & & & $\begin{array}{l}\text { Highly } \\
\text { effective }\end{array}$ \\
\hline & 1 & $\beta$ & 4 & 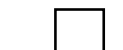 \\
\hline
\end{tabular}

$\mathrm{B}$

2

\begin{tabular}{|c|c|c|c|c|}
\hline Access to Scarce & $\begin{array}{l}\text { Highly } \\
\text { ineffective }\end{array}$ & & & $\begin{array}{l}\text { Highly } \\
\text { effective }\end{array}$ \\
\hline Kesources & 2 & 3 & 4 & \\
\hline
\end{tabular}

B

3

\begin{tabular}{|c|c|c|c|c|}
\hline Interconnection & $\begin{array}{l}\text { Highly } \\
\text { ineffective }\end{array}$ & & & $\begin{array}{l}\text { Highly } \\
\text { effective }\end{array}$ \\
\hline & $2 \Gamma$ & 3 & 4 & 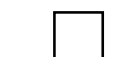 \\
\hline
\end{tabular}

B

4

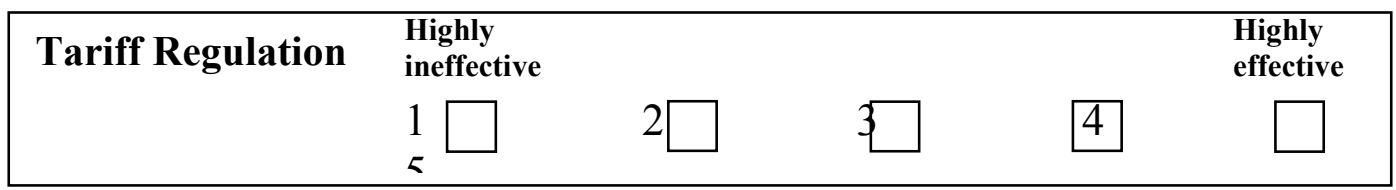

B

5

\begin{tabular}{|c|c|c|c|c|}
\hline Regulation of & $\begin{array}{l}\text { Highly } \\
\text { ineffective }\end{array}$ & & & $\begin{array}{l}\text { Highly } \\
\text { effective }\end{array}$ \\
\hline Anti-competitive & 1 & 3 & 4 & 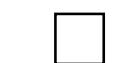 \\
\hline Practices & 5 & & & \\
\hline
\end{tabular}


B

6

\begin{tabular}{|c|c|c|c|c|}
\hline Universal Service & $\begin{array}{l}\text { Highly } \\
\text { ineffective }\end{array}$ & & & $\begin{array}{l}\text { Highly } \\
\text { effective }\end{array}$ \\
\hline Obligation (USO) & 1 & 3 & 4 & 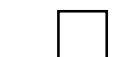 \\
\hline
\end{tabular}

B

7

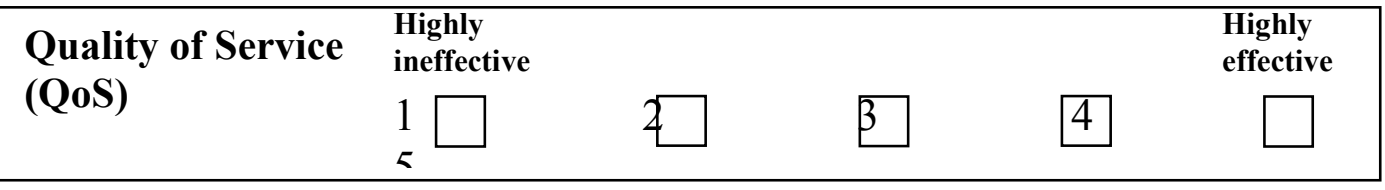

\section{Comments:}

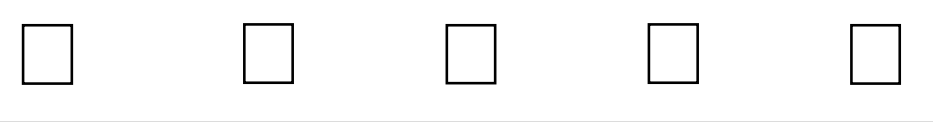


Annex 3: District-wise distribution of fixed phones (Non-CDMA and CDMA) as at December 2007

\begin{tabular}{|c|c|c|}
\hline District & Non-CDMA & CDMA \\
\hline Jaffna & 10,367 & 2,472 \\
\hline Mannar & 1,800 & 4,039 \\
\hline Vavuniya & 5,561 & 11,817 \\
\hline Trincomalee & 9,766 & 20,061 \\
\hline Batticaloa & 11,911 & 21,131 \\
\hline Kalmunai & 11,396 & 16,584 \\
\hline Ampara & 4,233 & 20,106 \\
\hline Anuradhapura & 16,554 & 98,948 \\
\hline Polonnaruwa & 8,373 & 40,550 \\
\hline Puttalam & 19,968 & 49,500 \\
\hline Kurunegala & 42,757 & 134,719 \\
\hline Negombo & 45,516 & 67,934 \\
\hline Matale & 16,843 & 45,638 \\
\hline Kandy & 45,488 & 97,633 \\
\hline Kegalle & 17,505 & 54,723 \\
\hline Nuwara Eliya & 6,118 & 25,657 \\
\hline Nawalapitiya & 21,513 & 22,533 \\
\hline Hatton & 6,375 & 25,895 \\
\hline Bandarawela & 12,399 & 38,535 \\
\hline Badulla & 10,829 & 54,035 \\
\hline Avissawella & 12,048 & 40,723 \\
\hline Ratnapura & 18,284 & 65,413 \\
\hline Moneragala & 0 & 21,261 \\
\hline Galle & 30,090 & 100,542 \\
\hline Matara & 27,534 & 71,710 \\
\hline Hambantota & 12,777 & 61,360 \\
\hline Colombo & 479,015 & 365,477 \\
\hline Gampaha & 53,599 & 48,093 \\
\hline Kalutara & 64,607 & 101,541 \\
\hline
\end{tabular}

Source: TRC 
Annex 4: Dialog 3G coverage map

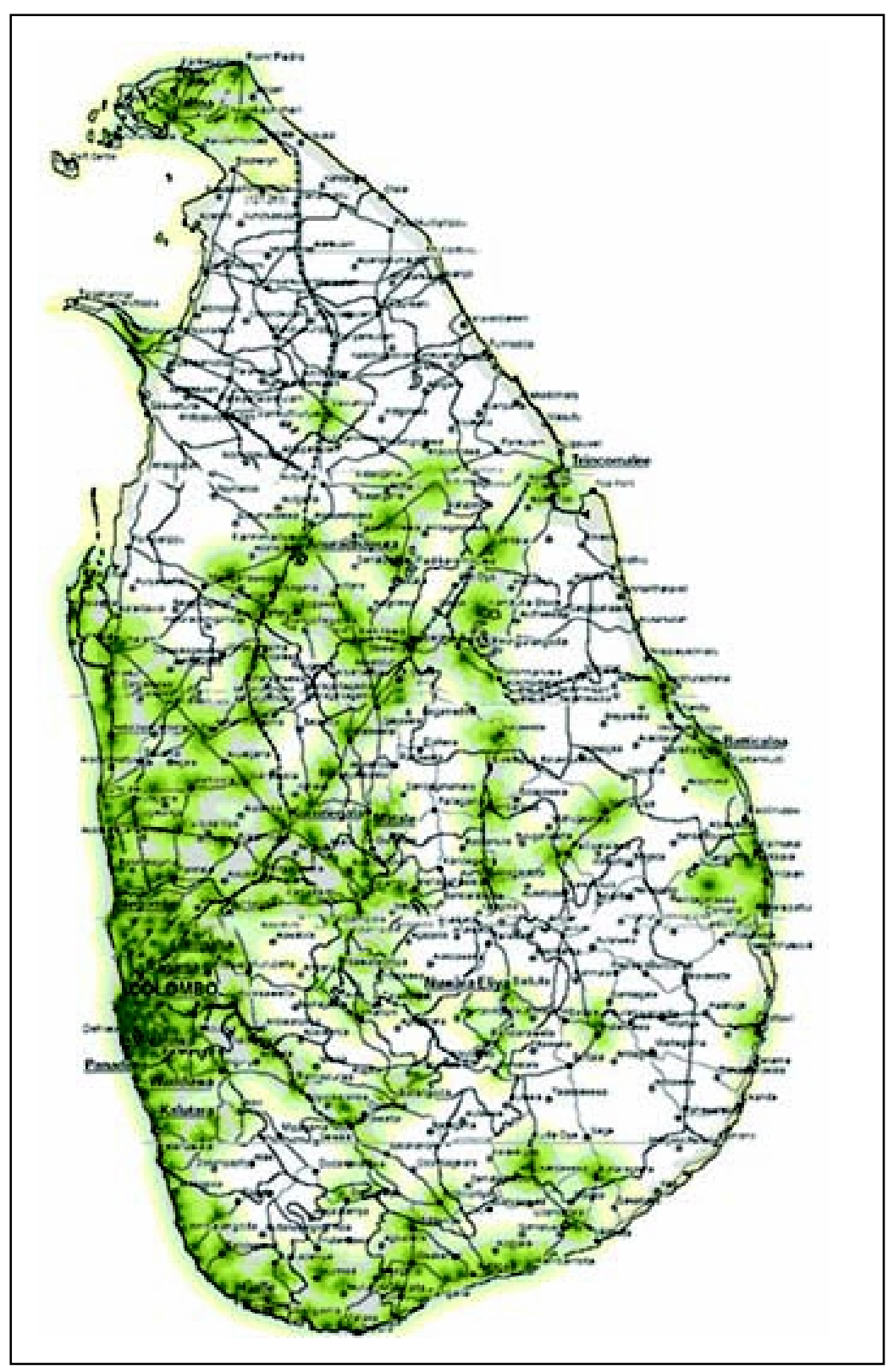

Source: Dialog Telekom, Annual Report, 2007. 
Annex 5: Dialog broadband coverage map

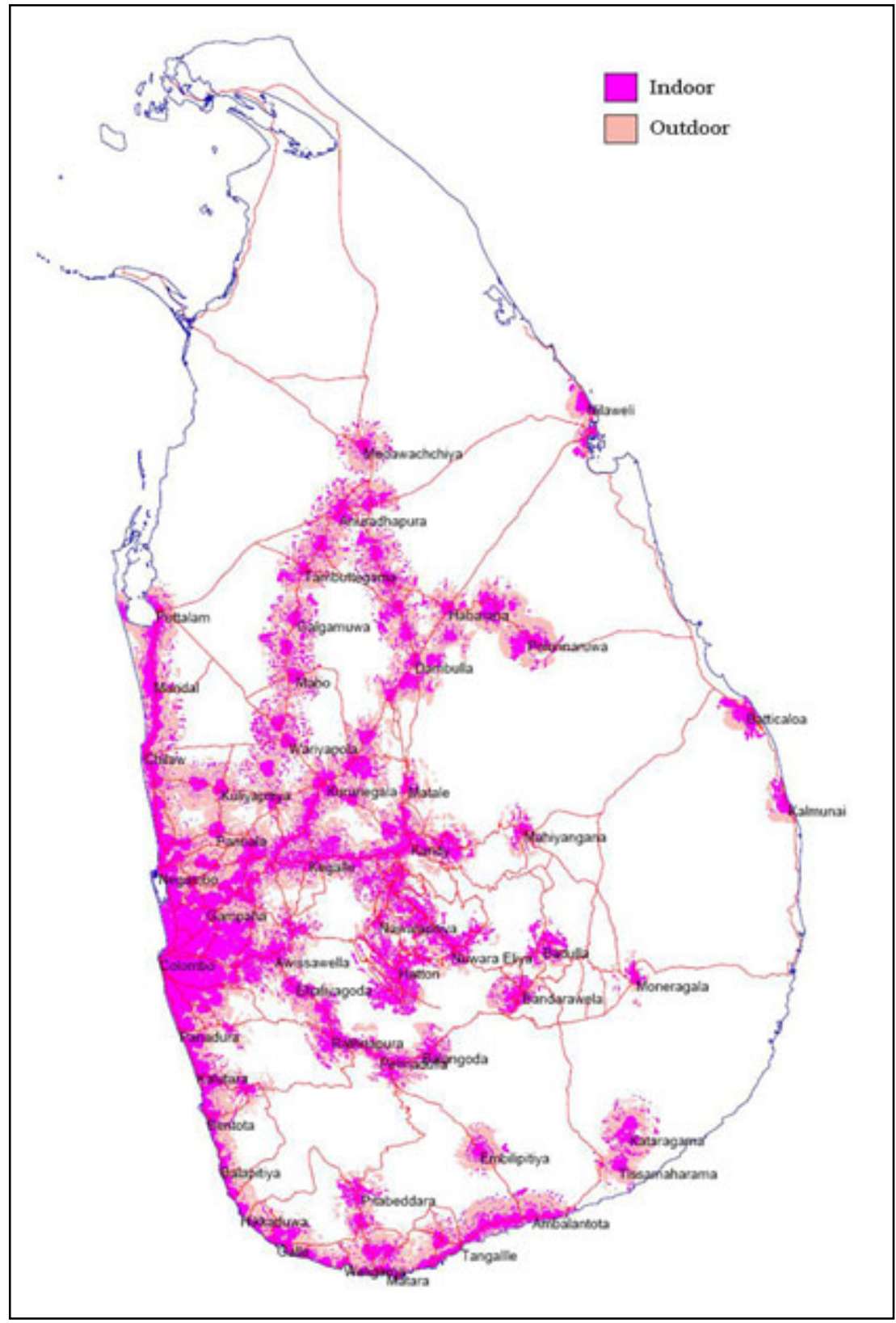

Source: Dialog Telekom, Annual Report, 2007. 
Annex 6: Fiber Optic Network Under SLTL

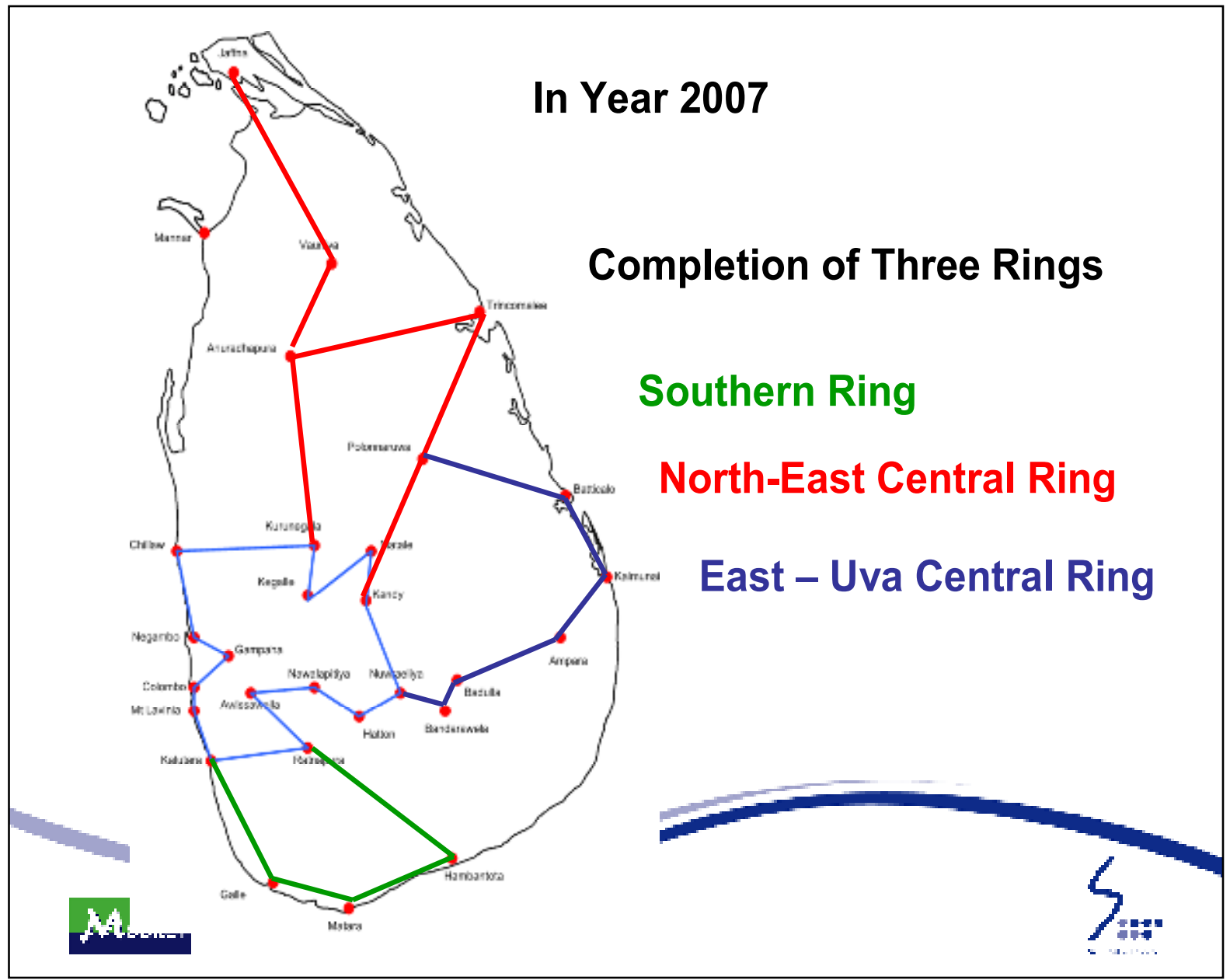

Source: SLTL, www.slt.lk

${ }^{7}$ The five Metro Rings were in full service as at December 2007. The Central Ring will be further upgraded in 2008. (SLTL Annual Reports, 2006 and 2007). 